\title{
Upholding Heightened Expectations of Indigenous Children? Parents do, Teachers do not.
}

\begin{tabular}{|c|l|}
\hline Journal: & The Australian Journal of Indigenous Education \\
\hline Manuscript ID & JIE-RA-2019-0025.R1 \\
\hline Manuscript Type: & Research Article \\
\hline Keywords: & $\begin{array}{l}\text { Expectations, Aboriginal and Torres Strait Islander, Children, Parents, } \\
\text { Teachers, Education }\end{array}$ \\
\hline Abstract: & $\begin{array}{l}\text { This paper argues that a component of the increase in the rate of } \\
\text { Aboriginal and/or Torres Strait Islander children and youths completing } \\
\text { their secondary education is the product of parents and teachers } \\
\text { maintaining high expectations of their children's/student's abilities to } \\
\text { succeed. To understand this, we investigate the importance of, and } \\
\text { discrepancies between, parent and teacher outlooks regarding } \\
\text { Indigenous youths completing year 12. The educational expectations } \\
\text { that parents and teachers have of Indigenous children, are a valuable } \\
\text { factor that can influence their educational success. Parents generally } \\
\text { maintain heightened prospects of their children successfully completing } \\
\text { secondary school, while teachers have lowered outlooks. This paper uses } \\
\text { quantitative data from the Longitudinal Study of Indigenous Children to } \\
\text { measure expectations from parents and teachers of Indigenous children. } \\
\text { Results suggest that parents maintain exceptionally high expectations of } \\
\text { their children, while teacher's expectations significantly decline over the } \\
\text { course of Indigenous children's primary and secondary schooling years. }\end{array}$ \\
\hline
\end{tabular}

\section{SCHOLARONE \\ Manuscripts}




\title{
Upholding Heightened Expectations of Indigenousi Children?
}

\section{Parents do, Teachers do not.}

\begin{abstract}
This paper argues that a component of increasing the rate of Aboriginal and Torres Strait Islander children and youths completing their secondary education, is having parents and teachers maintain heightened expectations of these children in achieving this goal. To understand this phenomena, we investigate the importance of, and discrepancies between, primary care giver ${ }^{1}$ and teacher outlooks regarding Indigenous youths completing year 12. This paper uses quantitative data from the Longitudinal Study of Indigenous Children to measure expectations from parents and teachers of Indigenous children. Results suggest that parents maintain exceptionally high expectations of their children, while teacher's expectations significantly decline over the course of Indigenous children's primary and secondary schooling years. We suggest that relationships and communication between parents and teachers, regarding expectations of students is important to establishing an equilibrium in expectations of children, and that teachers may benefit from further training to address any underlying biases towards Indigenous children.
\end{abstract}

Key Words: Quantitative, Indigenous Education, Primary and Secondary Schooling, Educational Achievement, Schooling Completion

\section{Introduction}

Teachers spend on average approximately 30 hours per week with children at the coalface of primary and secondary education. Given this not insignificant length of interaction between pupil and teacher, it is understandable that the expectations teachers have of their students can be influential in children's educational success and overall maturation into adulthood (Trudgett, Page, BodkinAndrews, Franklin, \& Whittaker, 2017). In recent years, the significance of teacher expectations and the interconnexion with student performance and wellbeing has been acknowledged in educational policy and research, particularly in respect to self-esteem and academic performance (Andersen, 2017; Riley \& Ungerleider, 2012). It has also been observed how "subtle" and subconscious racial assumptions (e.g. that those of a certain race are characteristically lazy), often based on unsubstantiated stereotypes, influences teachers' pedagogy and thereby unduly negatively affects

\footnotetext{
${ }^{1}$ For the purpose of this paper we adopt the term 'primary care giver' in place of parent. This is because the majority (87.7\%) of P1s analysed are the biological mothers with the remainder being close female relatives. P2's analysed are all male, 93.3\% are biological fathers; remainder are step-fathers or adoptive fathers.
} 
students' educational experiences (Vaught \& Castagno, 2008). Accordingly, an understanding of teacher expectations of their students, particularly those from minority groups such as Indigenous children, is of importance in contributing to the broader effort to improve the markedly lower educational outcomes of Indigenous Australians.

Parental-child expectations have similarly been shown to impact the educational achievement and overall scholastic success of their child(ren) overall (Bornholt \& Goodnow, 1999; Davis-Kean, 2005; Rubie-Davies, Peterson, Irving, Widdowson, \& Dixon, 2010) and within tertiary education (Koshy, Dockery, \& Seymour, 2019). This has primarily been the case in respect to the development of a child's self-concept in specific subjects (such as reading), and in response to their performance overall, studies finding that where parents have a higher expectation as to their child's performance, actively communicate and take interest in their child's homework and education, and encourage the acquisition of educative skills (e.g. reading) there tends to be a correlation with greater educational outcomes for their child (Castro et al., 2015). Notwithstanding this, it is noted that success is considered to be more holistic from an Indigenous perspective in comparison to the typical Western counterpart, given the former's valuing of culture, community and country (as opposed to the possession of health, wealth and status). Furthermore, Aboriginal and Torres Strait Islander children particularly benefit from parental confidence and support in buffering them against the risk factors and social structures negatively impacting them (Davis-Kean, 2005; Oostdam \& Hooge, 2013; RubieDavies et al., 2010).

This paper explores teacher and primary care giver expectations of Aboriginal and Torres Strait Islander children and their likelihood of successfully completing their secondary education, drawing from quantitative data from Waves 3-9 of the Longitudinal Study of Indigenous Children (hereinafter 'LSIC'). The results suggest primary care givers maintain exceptionally high expectations of their children, while teachers' expectations decline as the student progresses through the educational system. These lowered expectations of teachers are problematic because students, empirical research suggests, tend to attain greater levels of achievement when heightened expectations are maintained. From these findings we suggest primary care givers and teachers need to maintain forms of communication regarding student/children expectations as a means of balancing the expectations of both parties. In addition, we contend that teachers may benefit from the use of 'higher expectations strategy' and unconscious bias training within their tertiary learnings, and thereafter within professional development training, to remove unduly hindrances to the possession of bona fide expectations towards their Indigenous students. 


\section{Teachers and lowered expectations}

The interconnexion between teachers' expectations of their students and the level of the pupils' achievement has been increasingly examined since the late $20^{\text {th }}$ century, scholars noting a correlation in some instances between teacher expectations (high versus low) and the subsequent academic result attained by students (favourable versus not as favourable, see (Good, Sterzinger, \& Lavigne, 2018; Jussim \& Harber, 2005; Wang, Rubie-Davies, \& Meissel, 2018). Although there has been debate as to the extent to which this influence occurs, and the longevity of its affect (De Boer, Bosker, \& van der Werf, 2010), it has been agreed in recent years that this is a legitimate educational phenomena (Gentrup, Lorenz, Kristen, \& Kogan, 2020; Pantaleo, 2016, p. 83; Timmermans, Rubie-Davies, \& Rjosk, 2018; Wang et al., 2018). It is described as entailing a three-stage process, namely

I. Teachers possess predisposed expectations as to the educational ability and likely achievement of their students, which may be unduly influenced by stereotypes or similar unfounded assumptions (Dandy, Durkin, Barber, and Houghton (2015);

II. These predispositions guide teachers' pedagogy and interpersonal interactions and relationships with their students, with variation afforded to those deemed of greater potential than those with less (see also Elliot, 2011; Rosenthal \& Jacobson, 1968);

III. The pedagogy, attitudes and behaviour of teachers are observed and subsequently internalised by students leading some to, imbued with confidence and direction, focus and hone their skills and thereafter achieve more favourable results. Other students, who conversely, in the teacher's mind, have less potential, are either not encouraged or led to believe they are incapable, neglect to exert themselves in academics and receive less favourable results (Jacoby-Senghor, Sinclair, \& Shelton, 2016). This is known as a 'self-fulfilling prophecy' (Wang et al., 2018) or the 'stereotype threat' (Steele \& Aronson, 1995), where an individual accepts and conforms to (viz. embodies) the negative stereotyped label placed upon them (Hartley \& Sutton, 2013; Steele \& Aronson, 1995; Langdridge \& Butt, 2004; Mirels, 1980).

A leading area of inquiry in this field includes the examination of what predispositions teachers possess towards their students, and subsequently how these shape their everyday practice in the classroom (Gershenson, Holt, \& Papageorge, 2016; Van den Bergh, Denessen, Hornstra, Voeten, \& Holland, 2010; Wang et al., 2018). More specifically, attention has been afforded to testing and understanding the predispositions which stem from societal divisions of race, ethnicity, gender and socioeconomic status (Ali, 2010; Glock \& Krolak-Schwerdt, 2013). Indeed, even seemingly harmless implicit and/or unconscious assumptions may alter teacher-student interactions or treatment, and pedagogy; subsequently inducing students to internalise (and live up/down to) these expectations 
(e.g. belief in inability leading to lack of engagement and thereafter poor results, see (Riley \& Pidgeon, 2019; Watson et al., 2019)

Several studies have highlighted the presence of racial biases amongst teachers in primary and secondary schools, examining the subsequent effects on children (Chaffey, Bailey, \& Vine, 2015; Gershenson et al., 2016; Riley \& Ungerleider, 2012). It has been found in studies from the United States (Priest et al., 2018; Riley \& Ungerleider, 2012), Canada (Riley \& Ungerleider, 2012) and Australia (Chaffey et al., 2015) that white teachers tend to possess preconceived notions towards children of colour and academic success, perceiving black and Indigenous children to having less potential than white children. Indeed, Gershenson et al. (2016) found that non-African American teachers who taught African American students, possessed lower expectations (30-40\% lower) of their AfricanAmerican students' academic abilities in contrast to their non-African American counterparts. Similarly, Dandy et al. (2015) found that their sample of 199 Australian teachers tended to hold the view that Asian students were expected to perform better in mathematics and expend greater effort than Aboriginal and Anglo-Australian students, and that Anglo-Australian students to perform better than the Indigenous students.

Across these studies, the negative expectations of teachers towards specific classes of students (viz. by race) was shown to one of several variables which impacted student performance (Chaffey et al., 2015; Jacoby-Senghor, Sinclair, \& Shelton, 2016), mostly through the effort, attention and support given to those students (Jacoby-Senghor et al., 2016; Riley \& Ungerleider, 2012) This was further compounded when students received lowered test scores, thereby reinforcing reduced expectations in the minds of teachers (Jacoby-Senghor et al., 2016). Furthermore, it has been suggested that such negative expectations may increase over time, Priest et al. (2018) found that their sample demonstrated a growth in the perceived negative stereotypes against minority groups as the age of a cohort of children increased. It is worth noting that this may not always be an intentionally vindictive process, (Riley \& Ungerleider, 2012) note that some participants were reportedly unaware of biases negatively impacting students; though this may be the product of observation bias (Patton, 2014)

De Boer, Timmermans, and Van Der Werf (2018) in their review of 19 studies of initiatives to ameliorate negative teacher expectations towards students, observe that these measures tend to fall into one of three typologies, with some degree of overlap: (I) addressing behaviour of teacher; (II) addressing awareness of the effects of their expectations upon students; (III) rectifying predispositions of teachers. The scholars observe that rather than identifying the ideal program for changing teachers, it is instead necessary that teachers identify and acknowledge their prejudices, accept the unacceptableness of these, and affirm and implement means of change (De Boer et al., 2018). 
Needless to say, this is a difficult process as such self-examination and acknowledgement of fault requires vulnerability and humility, with the recanting and alteration of belief and behaviour often being lengthy and costly (De Boer et al., 2018).

\section{Parents and expectations}

The notion of parents maintaining heightened expectations is seen as an advantageous component of children achieving educational success (Bornholt \& Goodnow, 1999; Mau \& Bikos, 2000; Rimkute, Hirvonen, Tolvanen, Aunola, \& Nurmi, 2012; Rubie-Davies et al., 2010; Visser, 1987; Wentzel, 1998; Yamamoto \& Holloway, 2010). According to Yamamoto and Holloway (2010, p. 191), 'parental expectations are based on an assessment of the child's academic capabilities as well as the available resources for supporting a given level of achievement'. This is not to be confused with parent aspirations, which typically refers to the what parents want from their children, as opposed to what they expect, notwithstanding this, the two concepts are interrelated and sometimes used interchangeably (Juang \& Silbereisen, 2002; Yamamoto \& Holloway, 2010).

Studies have shown a correlational relationship between parents' expectations and their child's expectations; the higher the parent's expectations, the higher the children's expectations were of themselves (Visser, 1987; Wentzel, 1998; Zhang, Haddad, Torres, \& Chen, 2011). Consequently, parental expectations are likely to influence whether their children would undertake further study, e.g. tertiary education (Bodkin-Andrews, O'Rourke, \& Craven, 2010; Kickett-Tucker \& Coffin, 2011; Ma, 2001; Prehn, Peacock, \& Guerzoni, 2020).

Regarding Indigenous specific literature on parental expectations of children, little research is presently available; research instead exploring Indigenous parental aspirations for their children. However, work to date has found that Indigenous parents desire their children to attain a quality education, be successful, succeed, and grow up strong (Martin \& Walter, 2017, p. 56). Accordingly, our paper seeks to contribute to this gap in the literature regarding the formal schooling educational expectations within Indigenous families.

\section{Methodology}

This paper utilises an Indigenous quantitative methodological framework, involving the prioritising of an Australian Aboriginal worldview throughout each stage of the research process; conceptualisation, data analysis, interpretation and dissemination (Walter, Martin, \& Bodkin-Andrews, 2017, p. 3). The authors are Aboriginal men, each employed in an Australian tertiary educational institution in the field 
of social sciences. As such, acknowledging these social contexts and how they influence the researcher's held worldview is an important consideration (M Walter, 2013).

\section{The Longitudinal Study of Indigenous Children (LSIC)}

The LSIC 'collects information about the lives of Aboriginal and Torres Strait Islander children, their families and communities' (M Walter et al., 2017, p. 15). It is an Australia-wide panel study that commenced in 2008, boasting an original sample of approximately 1670 Aboriginal and Torres Strait Islander children and their families across 11 sites throughout Australia. These sites range from urban city centres, to extremely remote isolated communities (M Walter et al., 2017, p. 16).

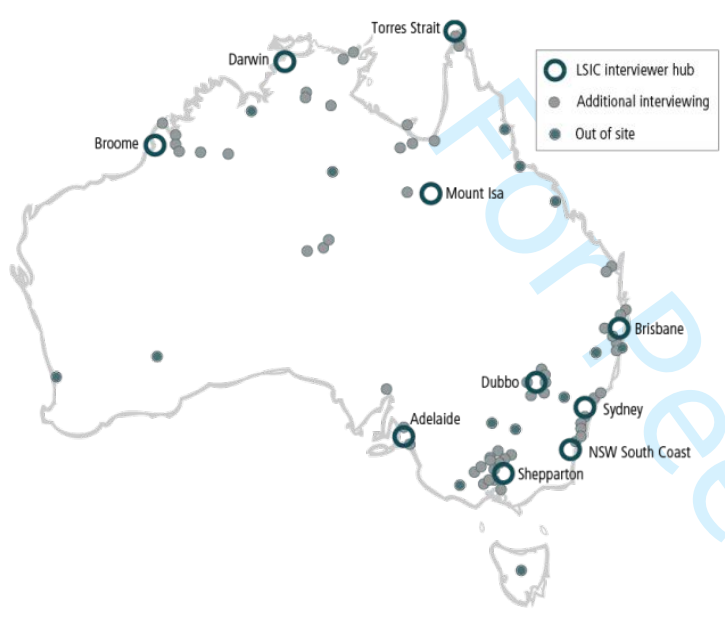

Figure 1: Longitudinal Study of Indigenous Children Data Collection Sites (Kneebone et al., 2012)

The LSIC was designed with two distinct cohorts of study children that are spaced approximately 3 years apart. These cohorts are known as the Baby Cohort (B Cohort) and the Kid Cohort (K Cohort). The children in the former cohort were between 6 months and 24 months old when the study started in 2008, and those within the $k$ cohort were aged three and a half to five years of age. As of 2020 the study has 10 publicly available Waves of data (each Wave constituting an additional year of data collection), with future waves to be realised annually (See figure 2.3).

Table 1: Ages of each cohort throughout the study

\begin{tabular}{|c|c|c|c|c|c|c|c|c|c|c|}
\hline & & 2008 & 2009 & 2010 & 2011 & 2012 & 2013 & 2014 & 2015 & 2016 \\
\hline & Born in & Wave 1 & Wave 2 & Wave 3 & Wave 4 & Wave 5 & Wave 6 & Wave 7 & Wave 8 & Wave 9 \\
\hline \multirow{3}{*}{ B cohort } & 2006 & \multirow{3}{*}{$\begin{array}{l}6 \text { months- } \\
2 \text { years }\end{array}$} & \multirow{3}{*}{$\begin{array}{l}11 / 2-3 \\
\text { years }\end{array}$} & \multirow{3}{*}{$\begin{array}{l}21 / 2-4 \\
\text { years }\end{array}$} & \multirow{3}{*}{$\begin{array}{l}31 / 2-5 \\
\text { years }\end{array}$} & \multirow{3}{*}{$\begin{array}{l}41 / 2-6 \\
\text { years }\end{array}$} & \multirow{3}{*}{$\begin{array}{l}51 / 2-7 \\
\text { years }\end{array}$} & \multirow{3}{*}{$\begin{array}{l}61 / 2-8 \\
\text { years }\end{array}$} & \multirow{3}{*}{$\begin{array}{l}71 / 2-9 \\
\text { years }\end{array}$} & \multirow{3}{*}{$\begin{array}{l}81 / 2-10 \\
\text { years }\end{array}$} \\
\hline & 2007 & & & & & & & & & \\
\hline & 2008 & & & & & & & & & \\
\hline \multirow{3}{*}{ K cohort } & 2003 & \multirow{3}{*}{$\begin{array}{l}31 / 2-5 \\
\text { years }\end{array}$} & \multirow{3}{*}{$\begin{array}{l}41 / 2-6 \\
\text { years }\end{array}$} & \multirow{3}{*}{$\begin{array}{l}51 / 2-7 \\
\text { years }\end{array}$} & \multirow{3}{*}{$\begin{array}{l}61 / 2-8 \\
\text { years }\end{array}$} & \multirow{3}{*}{$\begin{array}{l}71 / 2-9 \\
\text { years }\end{array}$} & \multirow{3}{*}{$\begin{array}{l}81 / 2-10 \\
\text { years }\end{array}$} & \multirow{3}{*}{$\begin{array}{c}91 / 2-11 \\
\text { years }\end{array}$} & \multirow{3}{*}{$\begin{array}{c}10 \frac{1}{2}-12 \\
\text { years }\end{array}$} & \multirow{3}{*}{$\begin{array}{c}11 \frac{1}{2}-13 \\
\text { years }\end{array}$} \\
\hline & 2004 & & & & & & & & & \\
\hline & 2005 & & & & & & & & & \\
\hline
\end{tabular}

Figure 2: Longitudinal Study of Indigenous Children Cohorts (Kneebone et al., 2012). 
The LSIC was designed with four overarching research questions in mind. These questions are formulated under the guidance of the dataset Steering Committee, they are:

- What do Indigenous children need to have the best start in life and to grow up strong?

- What helps Aboriginal and Torres Strait Islander children to stay on track or get them back on track to become healthier, more positive and stronger?

- How are Aboriginal and Torres Strait Islander children raised?

- What is the importance of family, extended family and community in the early years of life and when growing up? (M Walter et al., 2017, p. 22).

To support these overarching research themes, the study collects data on an expansive range of topics including inter alia, physical and mental wellbeing, social and cognitive development, education, and family and community factors (M Walter et al., 2017, p. 29). Accordingly, the LSIC is providing unequalled opportunities for current Indigenous and non-Indigenous researchers to contribute to improving outcomes for Indigenous children, their families and communities (Department of Social Services, 2016; M Walter et al., 2017). Yet it must be acknowledged that is not a perfect dataset; population statistics are often imbued with meaning derived from the dominant social norms, values and racial hierarchies of colonising nation-states.

Within this research, data from the K cohort Wave 3 (5.5-7 years of age) to Wave 9 (11.5-13 years of age) is analysed. Analysis is undertaken regarding how teachers and parents believe the study child (hereinafter ' $\mathrm{SC}^{\text {') }}$ will go in their education. All data analysis procedures are undertaken using the statistical software program SPSS (Version 24). Specifically, in this paper the variable "How far do you think SC will go in their education" in Waves 3 through 9 are analysed. This variable consists of 5 responses: [1] Leave school before finishing secondary school; [2] Complete secondary school; [3] Complete a trade or vocational training course; [4] Go to university and complete a degree, and; [5] Obtain postgraduate qualifications at a university. This variable was then recoded into a dichotomous yes/no. This recoded variable is re-named: “Do you believe SC will finish their secondary education?" With [0] No and [1] Yes being the options. The variable was recoded dichotomously through option [1] staying the same, and options [2] through [5] being combined. The same question is asked of the parents ( $\mathrm{P} 1$ and $\mathrm{P}^{2}$ ) and teachers of the SC. Teacher responses are analysed in Waves 3 through 9,

\footnotetext{
2 The majority (87.7\%) of P1s analysed are the biological mothers with the remainder being close female relatives. $\mathrm{P2}$ 's analysed are all male, $93.3 \%$ are biological fathers; remainder are step-fathers or adoptive fathers.
} 
whereas $\mathrm{P} 1$ and $\mathrm{P} 2$ responses are only analysed in Waves 5,8 and 9 as this question was not asked in other Waves. The analysis specifically reports on the percentage of parents and teachers in the study who selected 'Yes' or 'No in each Wave. Thereafter, one-way ANOVA analysis is undertaken to test for a statistically significant difference between group means; specifically testing whether there is a statistically significant difference between Wave 3 teacher expectations and Wave 9 teacher expectations.

\section{Results}

\section{Percentage of Primary Caregivers (P1) who Believe Child will Finish Their Secondary Education}

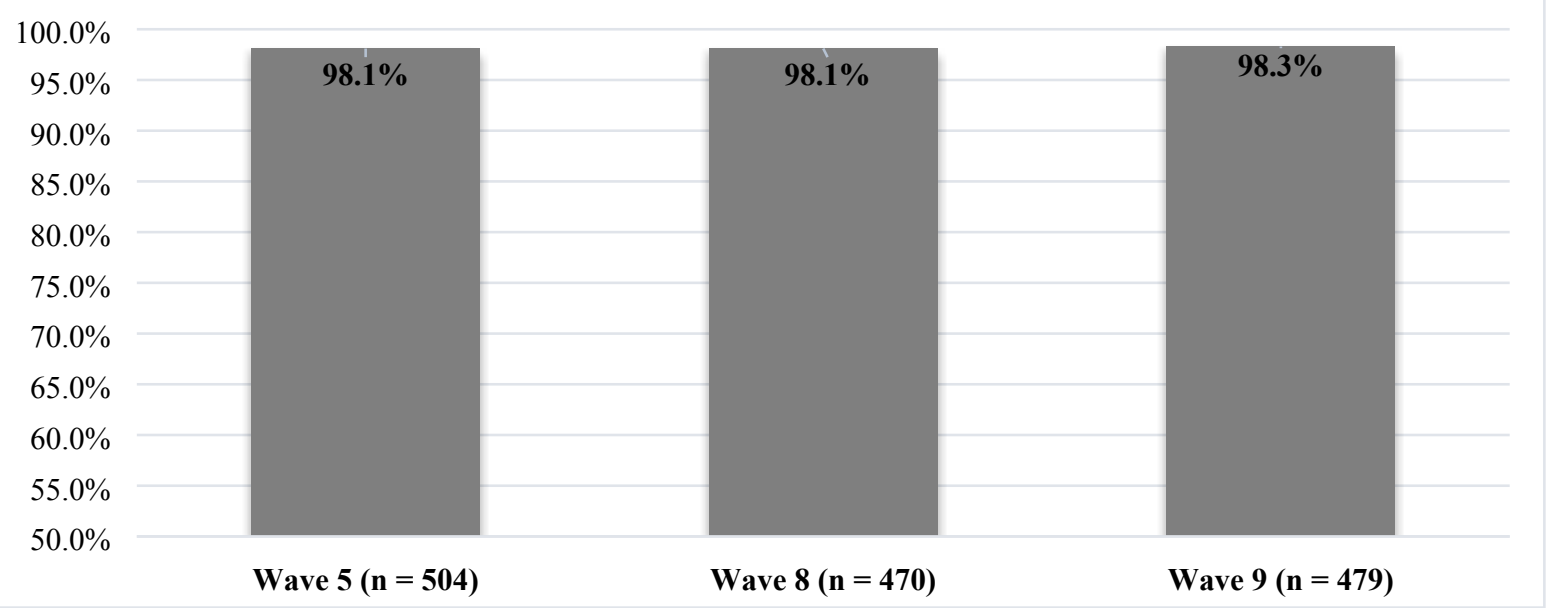

Figure 3: Primary caregiver (P1) expectations regarding their children completion secondary education.

\section{Percentage of Secondary caregivers (P2) who Believe Child will Complete Their Secondary Education}

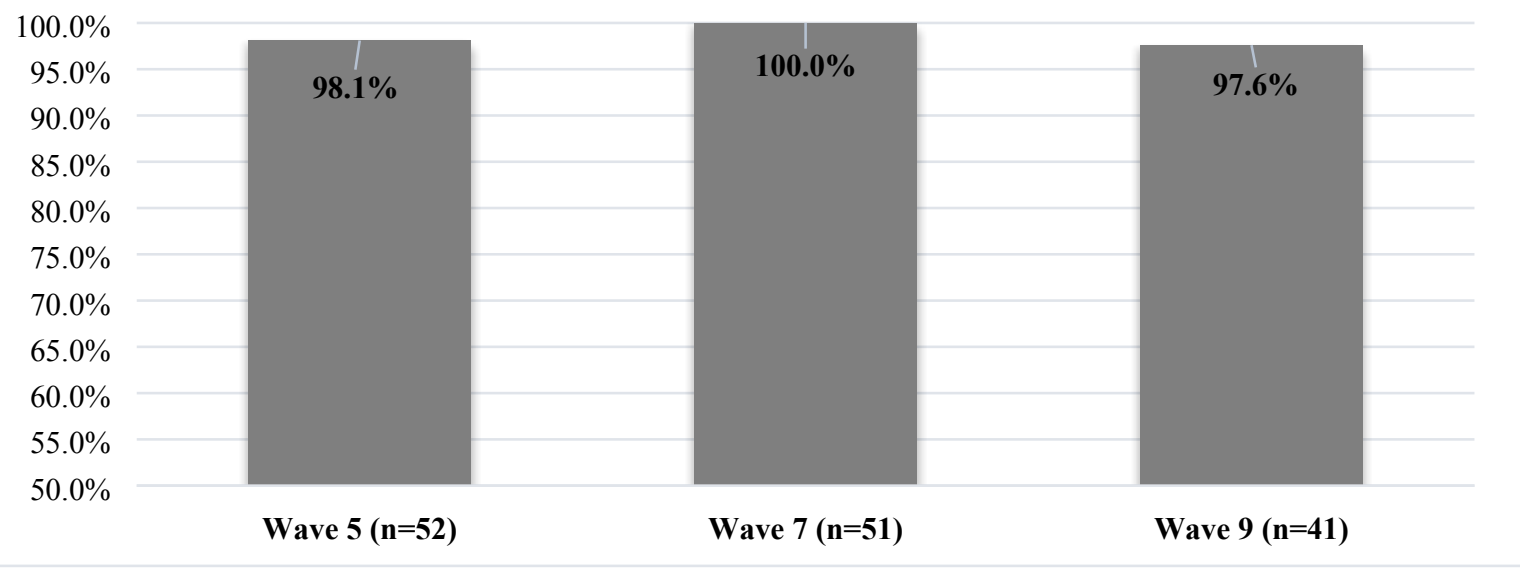

Figure 4: Secondary caregiver (P2) expectations their children completion secondary education.

\section{Key findings}

Close to all primary care giver's (P1s) and Secondary caregivers (P2s) believed their child would finish their secondary education in Waves 5, 8 and 9. Further, parent's responses did not significantly change over time. 


\section{Percentage of Teachers who Beleives Child will Finish Their Secondary Education}

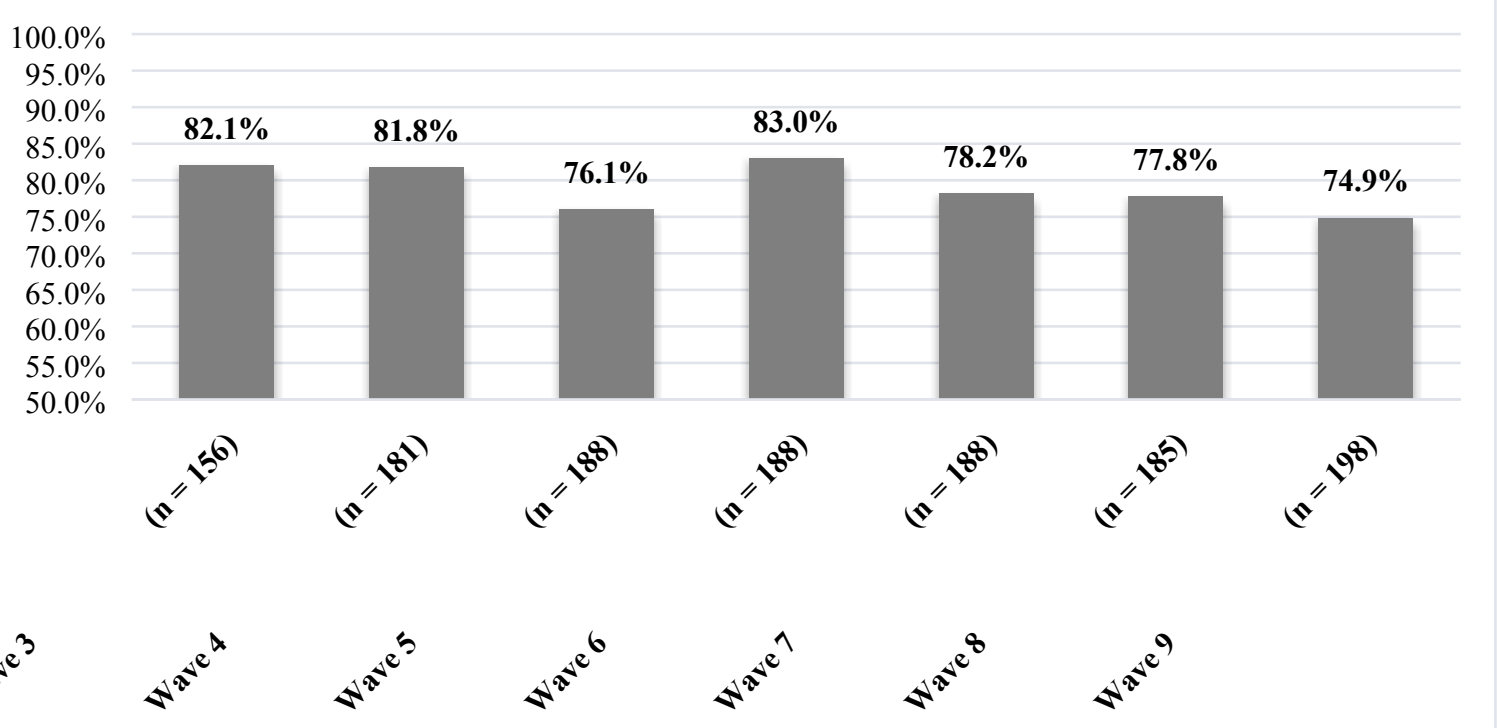

Figure 5: Teacher expectations regarding whether Indigenous children will complete secondary education.

Summary of ANOVA (Wave $3 v$ Wave 9)

\begin{tabular}{llllll}
\hline & $\begin{array}{l}\text { Sum } \\
\text { Squares }\end{array}$ & of & \multicolumn{2}{l}{ Mean } & \\
& & Square & $F$ & P \\
\hline Between Groups & 6521.4 & 1 & 6521.4 & 289.57 & $<.0001$ \\
\hline
\end{tabular}

Figure 6: ANOVA of Wave $3 \mathrm{v}$ Wave 9.

One Way ANOVA Analysis indicates that there is a statistically significant difference $[F(1)=289.57$ $p=<.0001$ ] between the group means of teacher expectations from wave 3 compared to Wave 9. Put simply this indicates that in Wave 9, teacher's expectations of SC are significantly different (Lower) than teacher expectations from Wave 3.

\section{Key findings}

Results indicate that Teachers' in higher-grade levels tend to report lower schooling completion expectations of the SC. As of wave 9 (when the children are between 11.5-13 years old), more than one quarter $(25.1 \%)$ of the teachers who responded indicated that they thought the child would leave school before finishing their secondary education, compared to $17.9 \%$ of the teachers from wave 3 , this difference is statistically significant.

\section{Discussion}


The aim of this paper was to understand the expectations of teachers and Indigenous primary care givers regarding the secondary schooling completion rates of their Indigenous students/children, which has previously not been undertaken in Australia. Our results confirm and align with previous literature in finding that teachers have comparatively lowered expectations as children progress through their formal schooling years, whilst parents, conversely, maintain high-level expectations of their children completing their secondary education. The expectation completion rates of formal year 12 schooling between teachers and parents regarding Aboriginal and Torres Strait Islander children is not surprisingly mismatched.

The data indicates that teacher's expectations of Indigenous children completing secondary education declines as the Indigenous children progress through their formal schooling levels. This finding correlates with other North American studies which described that sampled teachers had similar shifts in expectations throughout child maturation with students of minority ethnic groups (Jacoby-Senghor et al., 2016; Priest et al., 2018). It is of concern not only by virtue of the existence of such lowered expectations of Indigenous students per se, but also because this is shown to progressively worsen over time. In recognising that as Indigenous children mature to an age where their self-concept and self-esteem are crystallised, and entrance into university becomes a consideration, it is imperative that they receive additional affirmation, instruction and support from their teachers. Given that lowered expectations from teachers likely correlates with less support, and subsequently students achieving less favourable results, intentions or possibilities for Indigenous youth to pursue higher education or employment requiring further training may be unduly hindered, impeded or jettisoned. This is of concern insofar as educational achievement has been identified as one of the primary means of Indigenous people moving out of poverty and intergenerational inequality into which they are often deeply embedded (Martin \& Walter, 2017; M Walter et al., 2017).

As expected, parents maintain remarkably heightened expectations of their children regarding formal secondary school completion. Across the three Waves analysed, parent's expectations of their children's ability to complete secondary education, remain consistently high at over $98 \%$. Further, much like the primary caregivers, secondary caregivers (mostly Indigenous fathers) also maintained extraordinarily heightened prospects of their children schooling completion. This is an important finding because parental belief of children is found to contribute regarding favourable educational accomplishment through the development of their self-concept, and serves as a mitigating factor against structural inequalities facing Indigenous children (Rubie-Davies et al., 2010; Wentzel, 1998).

Our paper reaffirms the need for rectifying the lowered expectations that teachers have for Indigenous children, recognising that teachers are the single most important 'in school' influence on 
student achievement over peers and other personnel (Hattie, 2009). In recognising that teacher willingness is required to facilitate best outcomes in changes to beliefs and behaviours, we suggest that all teachers (and teacher aids) should be required to receive instruction in cultural competency and sensitivity training, which has support in Australia, as it is likely to produce improvements in the outcomes for Indigenous children (Harrison \& Greenfield, 2011; Owens, 2015). It is key that teachers be steered way from any prejudicial stereotypes that they may have towards Indigenous people, and led to respect and have compassion for Indigenous communities, culture and children (BodkinAndrews \& Carlson, 2016; M Walter, 2014).

Reflexivity towards attitudes and behaviours shown by teachers working with Indigenous children is a key component of this process (Ryan, 2017). There is a deficit discourse that Indigenous students are lower achievers, which has the potential to unconsciously impact teacher expectations of Indigenous students (Jacoby-Senghor et al., 2016). Teachers need to examine their own beliefs and behaviours to ascertain whether they have racial biases, and whether, and to what extent, this is affecting their practice. The Australian Professional Standards for Teachers could incorporate the importance of holding high expectations for Indigenous students under standard 1.4 (Strategies for teaching Aboriginal and Torres Strait Islander students) and/or 3.1 (Establish challenging learning goals). Furthermore, teacher cultural awareness programs could include an increase in unconscious bias training, alongside instruction outlining why maintaining high expectations of students (particularly those from minority groups) is needed to assist in ensuring the best results for students. More work is needed to further understand, the multifaceted issue of lowered teacher expectations, and in turn uncover how such a negative trend can be reversed. As Priest et al. (2018) states: perceptions of even small differences between groups can result in differential treatment with deleterious consequences.

In light of the meta-analysis findings from De Boer et al. (2018), one prominent strategy not mentioned is to improve teacher expectations through using 'High Expectation Relationships' (H-ER), to create high-quality relationships between students, teachers, families and the community. Students are more likely to feel supported and engaged in their education, as teachers are better able to understand and cater for their needs whilst maintaining heightened expectations (Stronger Smarter Institute, 2014). Chris Sarra suggests that this may be able to guard the classroom from racist and prejudicial practice Stronger Smarter Institute (2014). Sarra contends that when H-ER approaches are implemented within schools, students reportedly feel supported from their teachers and are more engaged in their education as a result. This may be because through using such strategies, teachers are positioned to better understand and cater for student individual needs, irrespective of race or 
disability, and focus on the development of high-quality relationships with students. Collectively, this may lead to a greater sense of inclusion within the schooling environment, further promoting student engagement (Stronger Smarter Institute, 2014, p. 14).

There are two overarching concepts of high expectation relationships used by the Stronger Smarter institute (SSI), these are 'fair' and 'firm' (see also Tatar and Horenczyk (2000). The notion of fair consists of active enquiry, and listening to students to understand their worldview (Stronger Smarter Institute, 2014, p. 5). This aspect of the H-ER framework is characterised through the cultivation and enaction of empathy and compassion, deep listening, genuine interest and a non-judgemental approach (Spillman, 2013). The concept of firm consists of 'critically reflective relating' (Spillman, 2013). This means having courage and firmness to address times when the individual student or broader community (both internal and external to the school) is not performing their responsibilities appropriately (viz. with restraint, appropriate to the understanding ability of the child, free of malice or ill-intent). Within the school environment, this involves challenging the deficit biases that teachers may have (Stronger Smarter Institute, 2014, p.6), while also enabling parents to more readily engage in their children's education. This close interaction of teachers with students may assist the former in discarding any held racial biases as a result of relating to the student as an individual, rather than as a member of a class.

It must be acknowledged that the implementations of such interventions, should abide by the recommendations of De Boer et al. (2018). Namely, creating a broad array of support for teachers, by providing them with tangible Information on expectations within their own context, as well as involving them in the design and implementations of such interventions (De Boer et al., 2018, p. 196). Further, we acknowledge that high expectations must be balanced against the competency of the student, i.e. being firm and fair.

We also recognise that tertiary education must lead the way in ameliorating biases of freshly-minted teachers, through the introduction of content and assessments which are embedded with Indigenous perspectives, and focus on confronting racist stereotypes (Bodkin-Andrews \& Carlson, 2016; Peters, 2016; Zubrzycki et al., 2014). Education courses could incorporate Indigenous graduate attributes and further Indigenise to assist in this process (Page, Trudgett and Bodkin-Andrews 2019). Put simply we are articulating that current teacher education programs could and should be improved to help alleviate prejudicial behaviours.

\section{Limitations}

It is important to acknowledge this study has limitations. One of the more prominent is the lowered number of teachers participating in LSIC. This may bias the results by producing better teacher 
expectations presented in the dataset than what is reality; which may be explained insofar as the teachers who decided to take the time to partake in the study are potentially more invested educators than those who did not. Further, this study is limited by the age of the children, i.e. the SC's high school years have not been analysed as the data was unavailable at this time. This should be followed up as subsequent Waves are released to observe any further expectational variation.

Another limitation is that quantitative measure of teachers' and caregivers' expectations of secondary school completion, is incapable of fully reflecting the expectations caregivers and teachers have of Indigenous children in their everyday lives at school. It also cannot explain caregivers' and teachers' values, support, and backgrounds or other influences that might affect school experience, which may be contributing to Indigenous students' educational achievement. More research is needed with regards to these important factors. Further research may also be required that investigates how teachers' attitudes, beliefs and perspectives from the different year groups, impact on Indigenous students' outcomes. Nonetheless, the expectation measure of school completion remains an important consideration in evaluating teachers' expectations of Indigenous children.

\section{Conclusion}

This paper has aimed to understand the expectations that parents and teachers have regarding Aboriginal and Torres Strait Islander children and their secondary schooling completion rates. The results suggest that the expectations of parents remain constant over the course of the child's primary school years. This is an encouraging finding, as parental expectations play a pivotal role in their child's educational success. Conversely, the expectations held by teachers decrease as Indigenous children progress through their formal schooling years. This is problematic because teachers play a central role in the lives of Indigenous children growing up strong in their education, as well as assisting them to overcome the negative impacts of structural disadvantage.

To alleviate the lowered expectations that teachers have of Indigenous students, we suggest improvements to schooling systems and teacher training. The decolonisation and Indigenisation of the Australian schooling system requires further progression. Through providing a decolonised educational environment within schools favourable to Indigenous students and their worldviews, the Indigeneity of Aboriginal and Torres Strait Islander students is normalised, working to curtail othering and racism against their personhood. For teachers, decolonisation may lead to the abrogation of existing negative stereotypical assumptions as to Indigenous student educational prospects, thereby potentially improving teachers' expectations to become closer to those of Indigenous parents. We recognise that universities must take-on Indigenisation and de-colonisation efforts within their 
curricula in order to ensure such change within the primary and secondary educational sectors; teaching degrees and diplomas may need to incorporate more explicit instruction and assessment which addresses topics such as racial bias, cultural sensitivity, and Indigenous pedagogy, to adequately shape the next generation of teachers (see Page, Trudgett, and Bodkin-Andrews (2019). For teachers already engaged in the workforce, undertaking professional development regarding unconscious bias, may assist in maintaining heightened but not patronising expectations of Indigenous students. Australia is a wealthy First World state, thus, through facilitating positive environments, and reconfiguring components to assist First-Nations children achieve educational success is an endeavour that can be achieved.

\section{References}

Ali, R. (2010). The formation and enactment of teacher expectations of student achievement in private schooling. TEACH Journal of Christian Education, 4(1), 10.

Andersen, C. (2017). Parent and Teacher Disconnect. Paper presented the Native American Indigenous Studies Association (NAISA) Conference, vancouver. 
Baxter, L. P., \& Meyers, N. M. (2016). Increasing urban Indigenous students' attendance: Mitigating the influence of poverty through community partnership. Australian Journal of Education, 60(3), 211-228.

Bodkin-Andrews, G., \& Carlson, B. (2016). The legacy of racism and Indigenous Australian identity within education. Race Ethnicity and Education, 19(4), 784-807.

Bodkin-Andrews, G., O'Rourke, V., \& Craven, R. (2010). The utility of general self-esteem and domain-specific self-concepts: Their influence on Indigenous and non-Indigenous students' educational outcomes. Australian Journal of Education, 54(3), 277-306.

Bodkin-Andrews, G., Whittaker, A., Cooper, E., Parada, R. H., Denson, N., \& Bansel, P. (2017). Moving beyond essentialism: Aboriginal parental perceptions of school bullying and school engagement. In M. Walter, K. L. Martin, \& G. Bodkin-Andrews (Eds.), Indigenous Children Growing Up Strong (pp. 153-178). London: Springer.

Bornholt, L. J., \& Goodnow, J. J. (1999). Cross-generation perceptions of academic competence: Parental expectations and adolescent self-disclosure. Journal of Adolescent Research, 14(4), 427-447.

Castro, M., Expósito-Casas, E., López-Martín, E., Lizasoain, L., Navarro-Asencio, E., \& Gaviria, J. L. (2015). Parental involvement on student academic achievement: A meta-analysis. Educational research review, 14, 33-46.

Chaffey, G. W., Bailey, S. B., \& Vine, K. W. (2015). Identifying high academic potential in Australian Aboriginal children using dynamic testing. Australasian Journal of Gifted Education, 24(2), 24.

Dandy, J., Durkin, K., Barber, B. L., \& Houghton, S. (2015). Academic expectations of Australian students from Aboriginal, Asian and Anglo backgrounds: Perspectives of teachers, traineeteachers and students. International Journal of Disability, Development and Education, 62(1), 60-82.

Davis-Kean, P. E. (2005). The influence of parent education and family income on child achievement: the indirect role of parental expectations and the home environment. Journal of family psychology, 19(2), 294.

De Boer, H., Bosker, R. J., \& van der Werf, M. P. (2010). Sustainability of teacher expectation bias effects on long-term student performance. Journal of Educational Psychology, 102(1), 168.

De Boer, H., Timmermans, A. C., \& Van Der Werf, M. P. (2018). The effects of teacher expectation interventions on teachers' expectations and student achievement: narrative review and meta-analysis. Educational Research and Evaluation, 24(3-5), 180-200.

Department of Education and Training. (2017). High Impact Teaching Strategies: Excellence in Teaching and Learning. Retrieved from Melbourne:

https://www.education.vic.gov.au/documents/school/teachers/support/highimpactteachstr at.pdf

Department of Social Services. (2016). Footprints in Time - The Longitudinal Study of Indigenous Children: Wave 7.

Gentrup, S., Lorenz, G., Kristen, C., \& Kogan, I. (2020). Self-fulfilling prophecies in the classroom: Teacher expectations, teacher feedback and student achievement. Learning and Instruction, 66, 101296.

Gershenson, S., Holt, S. B., \& Papageorge, N. W. (2016). Who believes in me? The effect of studentteacher demographic match on teacher expectations. Economics of Education Review, 52, 209-224.

Glock, S., \& Krolak-Schwerdt, S. (2013). Does nationality matter? The impact of stereotypical expectations on student teachers' judgments. Social Psychology of Education, 16(1), 111127.

Good, T. L., Sterzinger, N., \& Lavigne, A. (2018). Expectation effects: Pygmalion and the initial 20 years of research. Educational Research and Evaluation, 24(3-5), 99-123. 
Greenwald, A. G., \& Banaji, M. R. (1995). Implicit social cognition: attitudes, self-esteem, and stereotypes. Psychological review, 102(1), 4.

Harrison, N., \& Greenfield, M. (2011). Relationship to place: Positioning Aboriginal knowledge and perspectives in classroom pedagogies. Critical studies in education, 52(1), 65-76.

Hattie, J. A. (2009). Visible learning: A synthesis of $800+$ meta-analyses on achievement. Abingdon: Routledge.

Jacoby-Senghor, D. S., Sinclair, S., \& Shelton, J. N. (2016). A lesson in bias: The relationship between implicit racial bias and performance in pedagogical contexts. Journal of Experimental Social Psychology, 63, 50-55.

Juang, L. P., \& Silbereisen, R. K. (2002). The relationship between adolescent academic capability beliefs, parenting and school grades. Journal of adolescence, 25(1), 3-18.

Jussim, L., \& Harber, K. D. (2005). Teacher expectations and self-fulfilling prophecies: Knowns and unknowns, resolved and unresolved controversies. Personality and social psychology review, 9(2), 131-155.

Kickett-Tucker, C., \& Coffin, J. (2011). Aboriginal self-concept and racial identity: Practical solutions for teachers. Two way teaching and learning, 155-172.

Kneebone, L. B., Christelow, J., Neuendorf, A., \& Skelton, F. (2012). Footprints in time: the longitudinal study of indigenous children: an overview. Family Matters(91), 62.

Koshy, P., Dockery, A. M., \& Seymour, R. (2019). Parental expectations for young people's participation in higher education in Australia. Studies in Higher Education, 44(2), 302-317.

Landsman, J., \& Lewis, C. W. (2012). White teachers/diverse classrooms: Creating inclusive schools, building on students' diversity, and providing true educational equity: Stylus Publishing, LLC.

Luke, A., Cazden, C., \& Coopes, R. (2013). A summative evaluation of the stronger smarter learning communities project: Vol 1 and Vol 2.

Ma, X. (2001). Participation in advanced mathematics: Do expectation and influence of students, peers, teachers, and parents matter? Contemporary Educational Psychology, 26(1), 132-146.

Martin, K. L. (2017). Culture and identity: LSIC parents' beliefs and values and raising young Indigenous children in the twenty-first century. In M. Walter, K. L. Martin, \& G. BodkinAndrews (Eds.), Indigenous Children Growing Up Strong (pp. 79-99). London: Springer.

Martin, K. L., \& Walter, M. (2017). The Story of LSIC: It's All About Trust and Vision. In M. Walter, K. L. Martin, \& G. Bodkin-Andrews (Eds.), Indigenous Children Growing Up Strong (pp. 41-60). London: Springer.

Mau, W. C., \& Bikos, L. H. (2000). Educational and vocational aspirations of minority and female students: A longitudinal study. Journal of Counseling \& Development, 78(2), 186-194.

Mills, C. (2008). Making a difference: Moving beyond the superficial treatment of diversity. AsiaPacific Journal of Teacher Education, 36(4), 261-275.

Moodie, N., Maxwell, J., \& Rudolph, S. (2019). The impact of racism on the schooling experiences of Aboriginal and Torres Strait Islander students: A systematic review. The Australian Educational Researcher, 46(2), 273-295.

Oostdam, R., \& Hooge, E. (2013). Making the difference with active parenting; forming educational partnerships between parents and schools. European Journal of Psychology of Education, 28(2), 337-351.

Owens, K. (2015). Changing the teaching of mathematics for improved Indigenous education in a rural Australian city. Journal of Mathematics Teacher Education, 18(1), 53-78.

Page, S., Trudgett, M., \& Bodkin-Andrews, G. (2019). Creating a degree-focused pedagogical framework to guide Indigenous graduate attribute curriculum development. Higher Education, 78(1), 1-15.

Pantaleo, S. (2016). Teacher expectations and student literacy engagement and achievement. Literacy, 50(2), 83-92.

Patton, M. Q. (2014). Qualitative research \& evaluation methods: Integrating theory and practice: Sage publications. 
Peacock, H., \& Prehn, J. (2019). The importance of Aboriginal Education Workers for decolonising and promoting culture in primary schools: an analysis of the longitudinal study of Indigenous children (LSIC). The Australian Journal of Indigenous Education, 1-7. doi:10.1017/jie.2019.13

Peters, N. (2016). Learning shame: Colonial narratives as a tool for decolonization. M. Battiste, Visioning a Mi'Kmaw humanities: Indigenizing the academy, 149-164.

Prehn, J., Peacock, H., \& Guerzoni, M. A. (2020). Academic self-concepts of Aboriginal and/or Torres Strait Islander children from the Longitudinal Study of Indigenous Children. The Australian Journal of Indigenous Education, 1-10. doi:10.1017/jie.2019.26

Priest, N., Slopen, N., Woolford, S., Philip, J. T., Singer, D., Kauffman, A. D., . . Williams, D. (2018). Stereotyping across intersections of race and age: Racial stereotyping among White adults working with children. PloS one, 13(9), e0201696.

Prout Quicke, S., \& Biddle, N. (2017). School (non-) attendance and 'mobile cultures': theoretical and empirical insights from Indigenous Australia. Race Ethnicity and Education, 20(1), 57-71.

Riley, T., \& Pidgeon, M. (2019). Australian teachers voice their perceptions of the influences of stereotypes, mindsets and school structure on teachers' expectations of Indigenous students. Teaching Education, 30(2), 123-144.

Riley, T., \& Ungerleider, C. (2012). Self-fulfilling prophecy: How teachers' attributions, expectations, and stereotypes influence the learning opportunities afforded Aboriginal students. Canadian Journal of Education/Revue canadienne de l'éducation, 35(2), 303-333.

Rimkute, L., Hirvonen, R., Tolvanen, A., Aunola, K., \& Nurmi, J.-E. (2012). Parents' role in adolescents' educational expectations. Scandinavian Journal of Educational Research, 56(6), 571-590.

Rubie-Davies, C. M., Peterson, E., Irving, E., Widdowson, D., \& Dixon, R. (2010). Expectations of achievement: Student teacher and parent perceptions. Research in Education, 83(1), 36-53.

Ryan, C. (2017). Secondary School Teacher Effects on Student Achievement in Australian Schools. Retrieved from

Spillman, D. (2013). Towards a framework of dispositions, capabilities and cultural practices

for developing and enacting high-expectations relationships. University of Western

Sydney unpublished paper. .

Steele, C. M., \& Aronson, J. (1995). Stereotype threat and the intellectual test performance of African Americans. Journal of Personality and Social Psychology, 69(5), 797.

Stone, A., Walter, M., \& Peacock, H. (2017). Educational Outcomes For Aboriginal School Students In Tasmania: Is The Achievement Gap Closing? Australian and International Journal of Rural Education, 27(3), 90-110.

Stronger Smarter Institute. (2014). High-Expectations Relationships: a foundation for quality learning environments in all Australian schools. Stronger Smarter Institute: Limited Position Paper.

Tatar, M., \& Horenczyk, G. (2000). Parental expectations of their adolescents' teachers. Journal of adolescence, 23(4), 487-495.

Timmermans, A. C., Rubie-Davies, C. M., \& Rjosk, C. (2018). Pygmalion's 50th anniversary: the state of the art in teacher expectation research. In: Taylor \& Francis.

Trudgett, M., Page, S., Bodkin-Andrews, G., Franklin, C., \& Whittaker, A. (2017). Another brick in the wall? Parent perceptions of school educational experiences of Indigenous Australian children. In M. Walter, K. L. Martin, \& G. Bodkin-Andrews (Eds.), Indigenous Children Growing Up Strong (pp. 233-258). London: Springer.

Van den Bergh, L., Denessen, E., Hornstra, L., Voeten, M., \& Holland, R. W. (2010). The implicit prejudiced attitudes of teachers: Relations to teacher expectations and the ethnic achievement gap. American Educational Research Journal, 47(2), 497-527.

Vaught, S. E., \& Castagno, A. E. (2008). "I don't think I'm a racist": Critical Race Theory, teacher attitudes, and structural racism. Race Ethnicity and Education, 11(2), 95-113.

Visser, D. (1987). The relationship of parental attitudes and expectations to children's mathematics achievement behaviour. The Journal of Early Adolescence, 7(1), 1-12. 
Walter, M. (2013). The Nature of Social Science Research. In M. Walter (Ed.), Social Research Methods (3rd ed.). South Melbourne: Oxford University Press.

Walter, M. (2014). The Race Blind: Denying Australian Indigenous Rights. In J. Green (Ed.), (pp. 4356). Nova Scotia: Fernwood Publishing.

Walter, M. (2016). Data politics and Indigenous representation in Australian statistics. Indigenous Data Sovereignty: Toward an agenda, 38, 79.

Walter, M., Dodson, M., \& Barnes, S. (2017). Introducing the Longitudinal Study of Indigenous Children. In M. Walter, K. L. Martin, \& G. Bodkin-Andrews (Eds.), Indigenous Children Growing Up Strong (pp. 15-40). London: Springer.

Wang, S., Rubie-Davies, C. M., \& Meissel, K. (2018). A systematic review of the teacher expectation literature over the past 30 years. Educational Research and Evaluation, 24(3-5), 124-179.

Watson, P. W. S. J., Rubie-Davies, C. M., Meissel, K., Peterson, E. R., Flint, A., Garrett, L., \& McDonald, L. (2019). Teacher gender, and expectation of reading achievement in New Zealand elementary school students: essentially a barrier? Gender and Education, 31(8), 1000-1019.

Wentzel, K. R. (1998). Parents' aspirations for children's educational attainments: Relations to parental beliefs and social address variables. Merrill-Palmer Quarterly (1982-), 20-37.

Wolfe, P. (1999). Settler colonialism: A\&C Black.

Wolfe, P. (2006). Settler colonialism and the elimination of the native. Journal of Genocide Research, 8(4), 387-409. doi:10.1080/14623520601056240

Yamamoto, Y., \& Holloway, S. D. (2010). Parental expectations and children's academic performance in sociocultural context. Educational Psychology Review, 22(3), 189-214.

Zubrzycki, J., Green, S., Jones, V., Stratton, K., Young, S., \& Bessarab, D. (2014). Getting it right: Creating partnerships for change. Integrating Aboriginal and Torres Strait Islander knowledges in social work education and practice.

\footnotetext{
' The Longitudinal Study of Indigenous Children (LSIC) includes children that identify as Aboriginal, Torres Strait Islander and both Aboriginal and Torres Strait Islander. The usage of the term Indigenous in this paper is inclusive, and refers to both Aboriginal and/or Torres Strait Islander people.
} 


\section{Upholding Higheightenedh Expectations of Indigenous Children? Primary careParents givers-do, Teachers do not.}

\section{Abstract}

This paper argues that parta component of the increase in the rate a component ofincreasing the rate of Indigenous-Aboriginal and/or Torres Strait Islander children and youths increasing-completing their secondary schooling completion rateseducation ${ }_{, ;}$is having the product of parents and teachers maintenance-maintain of heightenedighheightened parent and teacher expectations of these children in achieving this goal-of their children's/student's abilities to succeed. To achieve-understand this phenomena, we investigates the importance of, and discrepancies between, teacher and primary care giver $^{1}$ and teacher expectationsoutlooks regarding Indigenous children in primary school_aged peopleyouths completing year 12-and the differences. The educational expectations that teachers and parents have of Aboriginal and Torres Strait Istander children, are a valuable component that can influence their educational success. Parent generally maintain heightened expectations Teachers frequently have lowered expectations of Indigenous children, a phenomenon this is observable from kindergarten through to undergraduate tertiary education. These reduced expectations are reportedly manifest along societal divisions of gender, race, ethnicity and socioeconomic status. Further, unconscious assumptions can alter teacher-student interactions, teaching performance or treatment, and induce students to internalise (and live down to) these lowered expectations, resulting in poorer academic outcomes. This paper explores teacher and parent expectations of Indigenous children; specifically, their expectations as to whether they think the children will successfully complete year 12. uses Qquantitative data from the Longitudinal Study of Indigenous Children is analysed-across multiple Waves-to measure expectations from parents and teachers, mothers and fathers of Indigenous children. Results suggest that parents maintain exceptionally high expectations of their children, while teacher's year 12 completion expectations significantly decline over the course of Indigenous children's primary primary and secondary sschooling years. We suggest that relationships and communication between parents and teachers, regarding expectations of students is important to establishing an equilibrium in expectations of children $\_$and that teachers may benefit from further training to address any underlying biases towards Indigenous children. advocate for ....

\footnotetext{
${ }^{1}$ For the purpose of this paper we adopt the term 'primary care giver' in place of parent. This is because the majority $(87.7 \%)$ of $\mathrm{P} 1 \mathrm{~s}$ analysed are the biological mothers with the remainder being close female relatives. P2's analysed are all male, $93.3 \%$ are biological fathers; remainder are step-fathers or adoptive fathers.
} 
These findings are then discussed in relation to the relevant literature, and suggestions are made regarding improving teacher expectations of $A$ boriginal and Torres Strait Islander children.

Key Words: Quantitative-Data, Indigenous Education, Primary and Secondary Schooling, Educational Achievement, Schooling Completion

\section{Chapter 4: Upholding High Expectations of Indigenous Children? Parents do, Teachers don't.}

\section{Abstract}

This paper investigates the importance of teacher and/parent expectations of Indigenous primary age children. The educational expectations that teachers and parents have of Aboriginal and Torres Strait Islander children are an important consideration when addressing their educational success. Teachers often have low expectations of Indigenous children and these low expectations, observable from kindergarten through to undergraduate levels, often manifest along societal divisions of gender, race, ethnicity and socioeconomic status. Even implicit, unconscious assumptions can alter teacher-student interactions, teaching performance or treatment, and induce students to internalise fand live down to) these low expectations, resulting in poorer outcomes. This paper explores teacherparent and teacher parent expectations of Indigenous children; specifically, their expectations as to whether they think the children will successfully complete year 12 . Quantitative data from the LSIC is analysed across multiple Waves to measure expectations from mothers, fathers and teachers and mothers and fathers of Indigenous children. Results will highlight the fact that parents maintain exceptionally high expectations of their children, while teacher's year 12 completion expectations significantly decline over the course of the children's primary school years. These findings are then discussed in relation to the relevant literature, and suggestions are made regarding improving teacher expectations of Aboriginal and Torres Strait Islander children.

Introduction

Teachers spend on average approximately 30 hours per week with children; working at at the coalface of primary and secondary education. Given this not insignificant length of interaction between pupil and teacher, it is understandable that the expectations teachers have of Indigenous their students can $\underline{\text { be influential in children's educational success and overall maturation into adulthood (Trudgett, Page, }}$ 
Bodkin-Andrews, Franklin, \& Whittaker, 2017). In recent years, the significance of teacher expectations and the interconnexion with student performance and wellbeing has been acknowledged in educational policy and research, particularly in respect to self-esteem and academic performance (Andersen, 2017; Riley \& Ungerleider, 2012). It has tooalso been observed how "subtle" and subconscious racial assumptions (e.g. that those of a certain race are characteristically lazy), whilst often based on unsubstantiated stereotypes, influences_teachers' pedagogy and thereby unduly

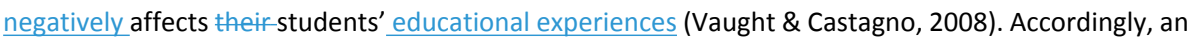
understanding of teacher expectations of their students, particularly those from minority groups such as Indigenous children, is of importance in contributing to the broader effort to improve the markedly lower educational outcomes of Indigenous Australians.

PThis is a location where societal attitudes and stereotypes can be projected upon Indigenous children. Conversely Tthe expectations teachers have of IndigenousAboriginal and Torres Strait Istander students are formativeinfluential in their educational success and ability to grow up strong (Trudgett et al., 2017). Teachers spend approximately 30 hours per week with children, working at the coalface of education; the point where societal attitudes and stereotypes are often projected upon Indigenous children. While overt racism is no longer tolerated inless socially acceptable in Australia, there are subtle and subconscious assumptions to consider which can influence teacher practice still negatively colour teachers' attitudes and expectations, resulting in disparity in pedagogical practice (Vaught \& Castagno, 2008). Subconscious assumptions or Implicit bias is the unconscious attribution of particular certain qualities to a member or members of a particular certain social group, that areis usually based on unsubstantiated stereotypes (Greenwald \& Banaji, 1995). The significance importance of teachers' expectations and the influenceeffect this can haveon student performance and wellbeing is beginning to beacknowledged in educational policy and research as something to monitor and correct, however, notwithstanding this realisation lower expectations of Indigenous students persevere (Andersen, 2017; Riley \& Ungerleider, 2012).

These prejudices exerted by canteachers, can alter teacher the performance and outcomes and judgement of students within their care sphere of influence.. , These prejudicespreconceptions have the ability to impact areas of student growth ultimately impacting on such students' self-esteem and academic performance_(Moodie, Maxwell, \& Rudolph, 2019). As such, when teaching marginalised groups such as Aboriginal and/or Torres Strait Istander students, minimalizing and overcoming factors which can negatively influence teacher bias is central for lowered Indigenous educational outcomes to be improved. As such, when teaching marginalised groups such as Aboriginaland/or Torres Strait Istander students, minimalizing and overcoming factors which can negatively influence teacher bias is imperative for overall Indigenous educational outcomes to be improved. (Wolfe, 1999, 2006) 
tt has been strongly argued that factors influencing academic achievement for Aboriginal and Torres Strait Islander school students is most likely tied to the schooling environments that do not adequately meet students' needs (Stone, Walter, \& Peacock, 2017). Addressing the low expectation tendencies of teachers is thus imperative for overall Indigenous educational outcomes to be improved.

Conversely, Similarly, pParental-child expectations of their children have similarly been are-shown to have an significantimpact on theirthe educational achievement $\bar{t}_{\bar{L}}$ and overall scholastic success of their child(ren) overall (Bornholt \& Goodnow, 1999; Davis-Kean, 2005; Rubie-Davies, Peterson, Irving, Widdowson, \& Dixon, 2010) and within tertiary education (Koshy, Dockery, \& Seymour, 2019). This has primarily been the case in respect to the development of a child's self-concept in specific subjects (such as reading), and in response to their performance overall, studies finding that where parents have a higher expectation as to their child's performance, actively communicate and take interest in their child's homework and education, and encourage the acquisition of educative skills (e.g. reading) there tends to be a correlation with greater educational outcomes for their child (Castro et al., 2015). Notwithstanding this, it is noted that success is considered to be more holistic from an Indigenous perspective in comparison to the typical Western counterpart ${ }_{2}$ given the former's valuing of culture, community and country (as opposed to the possession of health, wealth and status). Furthermore, Aboriginal and Torres Strait Islander children particularly benefit from parental confidence and support in buffering them against the risk factors and social structures negatively impacting Indigenous childrenthem (Davis-Kean, 2005; Oostdam \& Hooge, 2013; Rubie-Davies et al., 2010).

parents also-serve an important role in the formation of theirchildren's self-esteem and self-concept through socialisation; Aboriginal and Torres Strait Istander children benefit from their parents' confidence and support in this regard, which overflows in countering risk factors and social structures negatively impacting Indigenous children (Davis-Kean, 2005; Oostdam \& Hooge, 2013; Rubie-Davies et al., 2010).From an Aboriginal and Torres Strait Islander perspective, success is considered to be more more holistic than the Western focus on health and educational achievement. Indigenous notions of success include, and includes the possession of knowledge of family, culture, and land/Country (land/nature) each of which are interwoven in the formation of identity and character (Martin \& Walter, 2017).

Consequently, Indigenous parental expectations can be at odds with the Western perspectives on education and values important to children in conceptualising education as encompassing more than what the Western system typically provides and shapes children to desire. Notwithstanding possessing high expectations, parents also serve an important role in the formation of their children's self-esteem and self-concept through socialisation; Aboriginal and Torres Strait Istander children 
benefit from their parents' confidence and support in this regard, which overflows in countering risk factors and social structures negatively impacting Indigenous children (Davis-Kean, 2005; 0ostdam \& Hooge, 2013; Rubie-Davies et al., 2010).

Given this, Tthis paper chapter explores parent $\underline{t \mp e a c h e r}$ and teacher primary care giver expectations of Indigenous Aboriginal and/or Torres Strait Islander children and their likelihood of $;$ sSpecifically, their expectations as to whether they think the children their parent or teach will-successfully complete-completing ¥year 12their secondary education-- drawing from $Q$ quantitative univariate data from Waves 3-9 of the LSIC Kid CohortLongitudinal Study of Indigenous Children (hereinafter 'LSIC'). is analysed across multiple Waves to measure expectations from tTeachers, mothers and, fathers and teachers, of Indigenous children._(Kneebone, Christelow, Neuendorf, \& Skelton, 2012; M Walter, Dodson, \& Barnes, 2017)The results suggest primary care givers maintain exceptionally high expectations of their children, while teachers' expectations decline as the student progresses through the educational system. These lowered expectations of teachers are problematic because students, empirical research suggests, tend to attain greater levels of achievement when heightened expectations are maintained. From these findings we suggest unconscious bias training be integrated into tertiary curriculum for pre-service teachers and undertaken for current service teachers professional development courses.primary care givers and teachers need to maintain forms of communication regarding student/children expectations as a means of balancing the expectations of both parties. In addition, we contend that teachers may benefit from the use of 'higher expectations strategy' and unconscious bias training within their tertiary learningsformation ${ }_{L}$ and thereafter within professional development training $\angle$ to remove unduly hindrances to the possession of bona fide expectations towards their Indigenous students.

\section{Literature Review}

\section{Teachers and lowered expectations}

The interconnexion between explored-teachers' expectations of their students and the level of the pupils' achievement has been increasingly examined since the late $20^{\text {th }}$ century, scholars noting a correlation in some instances between teacher expectations (high versus low) and the subsequent academic result attained by students (favourable versus not as favourable, see (Good, Sterzinger, \& Lavigne, 2018; Jussim \& Harber, 2005; Wang, Rubie-Davies, \& Meissel, 2018). Although there has been debate as to the extent to which this influence occurs, and the longevity of its affect (De Boer, Bosker, 
\& van der Werf, 2010), it has been agreed in recent years that this is a legitimate educational phenomena (Gentrup, Lorenz, Kristen, \& Kogan, 2020; Pantaleo, 2016, p. 83; Timmermans, RubieDavies, \& Rjosk, 2018; Wang et al., 2018). It is described as entailing a three-stage process, namely

-1. Teachers possess predisposed expectations as to the educational ability and likely achievement of their students, which may be unduly influenced by stereotypes or similar unfounded assumptions (Dandy, Durkin, Barber, and Houghton (2015);

"11. These predispositions guide teachers' pedagogy and interpersonal interactions and relationships with their students, with variation afforded to those deemed of greater potential than those with less (see also Elliot, 2011; Rosenthal \& Jacobson, 1968);

IIII. The pedagogy, attitudes and behaviour of teachers are observed and subsequently internalised by students leading some to, imbued with confidence and direction, focus and hone their skills and thereafter achieve more favourable results. Other students, who conversely ${ }_{L}$ in the teacher's mind, have less potential, are either not encouraged or led to believe they are incapable, neglect to exert themselves in academics and receive less favourable results (Jacoby-Senghor, Sinclair, \& Shelton, 2016). This is known as a 'self-fulfilling prophecy' (Wang et al., 2018) or the 'stereotype threat' (Steele \& Aronson, 1995), where an individual accepts and conforms to (viz. embodies) the negative stereotyped label placed upon them (Hartley \& Sutton, 2013; Steele \& Aronson, 1995; Langdridge \& Butt, 2004; Mirels, 1980).

A leading area of inquiry in this field includes the examination of what predispositions teachers possess towards their students, and subsequently how these shape their everyday practice in the classroom (Gershenson, Holt, \& Papageorge, 2016; Van den Bergh, Denessen, Hornstra, Voeten, \& Holland, 2010; Wang et al., 2018). More specifically, attention has been afforded to testing and understanding the predispositions which stem from towards-societal divisions of race, ethnicity, gender and socioeconomic status (Ali, 2010; Glock \& Krolak-Schwerdt, 2013). Indeed, Eeven seemingly harmless implicit and/or unconscious assumptions may_alter teacher-student interactions or treatment, and teaching performancepedagogy-or treatment; subsequently inducing students to internalise (and live up/down to) these expectations (e.g. belief in inability leading to lack of engagement and subsequently thereafter poor results, see (Riley \& Pidgeon, 2019; Watson et al., 2019)

Several studies have highlighted the presence of racial biases amongst teachers in primary and secondary schools, examining the subsequent effects on children (Chaffey, Bailey, \& Vine, 2015; Gershenson et al., 2016; Riley \& Ungerleider, 2012). It has been found in studies from the United States (Priest et al., 2018; Riley \& Ungerleider, 2012), Canada (Riley \& Ungerleider, 2012) and Australia 
(Chaffey et al., 2015) that white teachers tend to possess preconceived notions towards children of colour and academic success, perceiving black and Indigenous children to having less potential than white children. Indeed, Gershenson et al. (2016) found that non-African American teachers who taught African American students, possessed lower markedly lowered expectations (30-40\% lower) of their African-American students' academic abilities in comparisoncontrast to than-their non-African American counterparts. It was found that African-American teachers' expectations of African American students TheseThe scholars found that cross-racial biases were primarily attributed to social factors. Similarly, Dandy et al. (2015) found that their sample of 199 Australian teachers tended to hold the view that Asian students were expected to perform better in mathematics andmathematics and expend greater effort than Aboriginal and Anglo-Australian students-, and In turn, while the teachers alsoexpectedthat Anglo-Australian students to perform better than the Indigenous students. Across these studies, the negative expectations of teachers towards specific classes of students (viz. by race) was shown to one of several variables which affected impacted student performance (Chaffey et al., 2015; Jacoby-Senghor, Sinclair, \& Shelton, 2016), mostly through the effort, attention and support given to those students (Jacoby-Senghor et al., 2016; Riley \& Ungerleider, 2012) This was impactfurther snowballedcompounded when sStudents achieving received lowered test scores, thereby and, thus reinforceding negative lowreduced expectations in the minds of teachers (JacobySenghor et al., 2016). Furthermore, it has been suggested that such negative expectations may increase over time, Priest et al. (2018) found that their sample demonstrated a growth in the perceived negative stereotypes ofagainst minority groups as the aged of a cohort of children increased. It is worth noting that this may not always be an intentionally vindictive process, (Riley \& Ungerleider, 2012) note that some participants were reportedly unconsciously-aware of the-biases that were negatively impacting on theirstudents; though this may be the product of observation bias (Patton, 2014), though this may be evidence of self-preservation on the part of participants

De Boer, Timmermans, and Van Der Werf (2018) in their review of 19 studies of initiatives to ameliorate negative teacher expectations towards students, observe that these measures tend to fall into one of three typologies, with some degree of overlap: (I) addressing behaviour of teacher; (II) addressing awareness of the effects of their expectations upon students; (III) rectifying predispositions of teachers. The scholars observe that rather than identifying the ideal program for changing teachers, it is instead necessary that teachers identify and acknowledge their prejudices, accept the unacceptableness of these, and affirm and implement mean-s of change (De Boer et al., 2018). Needles-s to say, this is a difficult process as such self-examination and acknowledgement of fault requires vulnerability and humility, with the recanting and alteration of belief and behaviour often being lengthy and costly (De Boer et al., 2018). 
\#77

Although the SSI's idea H-ER has merit However, there has been az critique of Sarra's past work in relation to the Stronger Smarter Learning Communities (SSLC) Project that comes from Luke, Cazden, and Coopes (2013). In their critic of this Stronger Smarter Institute program, They suggests that while the stronger smarter institute correctly recognises that deficit thinking is prevalent in schools, it may lack the necessary approach to actual reform, as schools continue to be run from an deficit approach. tuke et al. (2013) also found that the stronger smarter model has no official evidence of improving actual attendance and achievement.

Commented [HP2]: Bring this back to a positive

Although the SSI's idea H-ER has merit However, there has been aaA creticritiquec of Sarra's past work in relation to the Stronger Smarter Learning Communities (SSLC) Project that comes from-Luke et al. (2013) In their critic of this Stronger Smarter Institute program, They suggests that while the stronger smarter institute correctly recognises that deficit thinking is prevalent in schools, it may lack the necessary approach to actual reform, as schools continue to be run from an deficit approach. Luke et al. (2013) also found that the stronger smarter model has no official evidence of improving actual attendance and achievement.

Parents and expectations

The notion of parents maintaining heightened expectations is seen as an advantageous component of theirchildren achieving educational success (Bornholt \& Goodnow, 1999; Mau \& Bikos, 2000; Rimkute, Hirvonen, Tolvanen, Aunola, \& Nurmi, 2012; Rubie-Davies et al., 2010; Visser, 1987; Wentzel, 1998; Yamamoto \& Holloway, 2010). As aforementioned, parental expectations are also found to play an important role on their child's educational attainment, self-perception and ability to reach adulthooc in possession of favourable mental and physical health outcomes (Bornholt \& Goodnow, 1999; Mau \& Bikos, 2000; Rubie-Davies et al., 2010; Visser, 1987; Wentzel, 1998; Yamamoto \& Holloway, 2010).

According to Yamamoto and Holloway (2010, p. 191) $)_{L^{-}}$'Pparental expectations are based on an assessment of the child's academic capabilities as well as the available resources for supporting a given level of achievement'. This is not to be confused with parent aspirations, which are-typically refers to the what parents want from their children, as opposed to what they expect, notwithstanding ththis, at. Having said that they are often highlyAlthough the two concepts are interrelated and sometimes used interchangeably (Juang \& Silbereisen, 2002; Yamamoto \& Holloway, 2010). 
Studies have shown a correlational relationship between parents' expectations and their child's expectations; the higher the parent's expectations, the higher the children's expectations were of themselves (Visser, 1987; Wentzel, 1998; Zhang, Haddad, Torres, \& Chen, 2011). Consequently, parental expectations-ofn their children $n_{\bar{L}}$ are more-likely to influence whether their children would go to universityundertake further study, e.g. tertiary education (Ma, 2001; (Bodkin-Andrews, O'Rourke, \& Craven, 2010; Kickett-Tucker \& Coffin, 2011; Ma, 2001; Prehn, Peacock, \& Guerzoni, 2020). In regards toRegarding Indigenous specific literature on parental expectations of Indigenous children, little research is presently available; research instead exploring -Indigenous pParentals aspirations for their children. However, work to date has found that Indigenous parents desire their children to go to school andattain a quality have a good education, be successful, succeed in whatever they want to do, and grow upbe strong (Martin \& Walter, 2017, p. 56). Accordingly, our paper seeks to contribute to this gap in the literature regarding the formal schooling educational expectationsparental beliefs about education may also be an important factor, Martin (2017, pp. 94-95) Identifies that, inter alia, parents believe that Indigenous children will grow up strong if they learn from their Elders in the community, and learn about their culture, heritage an connection of country. _within Indigenous families.

HLiterature using LSIC the longitudinal study of Indigenous children (LSIC) data has identified the importance of schools facilitating a relationship between Aboriginal parents and the school (BodkinAndrews et al., 2017; Trudgett et al., 2017). Facilitating culturally appropriate school environments are also identified as an important consideration in helping Indigenous families feel welcome and comfortable when visiting their child's school (Baxter \& Mevers, 2016; Prout Quicke \& Biddle, 2017). Feaching and teachers are clearly an important aspect in this respect.

\section{MORE LIT NEEDED? (Yamamoto \& Holloway, 2010)}

\section{Methodology}

This paper utilises uses-an Indigenous quantitative methodological framework-, This-involvesing the prioritising of an Australian Aboriginal worldview throughout each stage of the research process,-; this includes conceptualisation, data analysis, interpretation and dissemination (\{Walter, 2013 \#565\}Walter, Martin, \& Bodkin-Andrews, 2017, p. 3). The authors are Aboriginal malesmen, each employed in an Australian tertiary educational institution, in the field of social sciencesology. As such, acknowledging how these social contexts and how they influence their researcher's held worldview is an valuableimportant consideration (M Walter, 2013). and the framing of this paper is important.

Commented [HP4]: Not quite related... take out or rework?

Commented [HP5]: I will find 


\section{The ESIE}

LSIC 'is a study collects information about the lives of Aboriginal and Torres Strait Islander children, their families and communities' (M Walter et al., 2017, p. 15). It is an Australia--wide panel study that commenced in 2008, withboasting an original sample of approximately 1670 Aboriginal and/or Torres

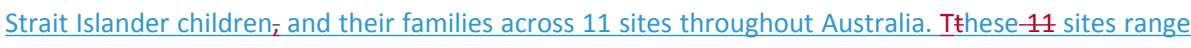
from urban city centres, to extremely remote isolated communities (M Walter et al., 2017, p. 16).

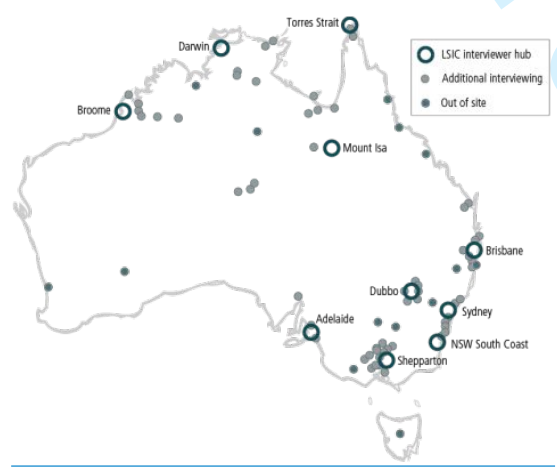

Figure XX1: Longitudinal Study of Indigenous Children Data Collection LSIC-Sites (Kneebone et al., 2012)

The LSIC wasiswas designed with two distinct cohorts of sStudy children that are spaced approximately 3 years apart. $\overline{\bar{\gamma}}$ Tthese cohorts are known as the Baby Cohort (B Cohort) and the Kid Cohort (K Cohort). The children in the former cohort were between 6 months and 24 months old when the study started in 2008, and those within the k cohort were aged three and a half to five years of age. InAs of 2020- Fthe study eurrently has 10 publicly available Waves of data (each Wave constituting an additional year of data collection), with future waves to be realised annually (See figure 2.3). From data collection to data release is usually a two year turn around, so wave 11 should be released in 2020. 


\begin{tabular}{|c|c|c|c|c|c|c|c|c|c|c|}
\hline & & 2008 & 2009 & 2010 & 2011 & 2012 & 2013 & 2014 & 2015 & 2016 \\
\hline & Born in & Wave 1 & Wave 2 & Wave 3 & Wave 4 & Wave 5 & Wave 6 & Wave 7 & Wave 8 & Wave 9 \\
\hline \multirow{3}{*}{ B cohort } & 2006 & \multirow{3}{*}{$\begin{array}{l}6 \text { months- } \\
2 \text { years }\end{array}$} & \multirow{3}{*}{$\begin{array}{l}11 / 2-3 \\
\text { years }\end{array}$} & \multirow{3}{*}{$\begin{array}{l}21 / 2-4 \\
\text { years }\end{array}$} & \multirow{3}{*}{$\begin{array}{l}31 / 2-5 \\
\text { years }\end{array}$} & \multirow{3}{*}{$\begin{array}{l}41 / 2-6 \\
\text { years }\end{array}$} & \multirow{3}{*}{$\begin{array}{l}51 / 2-7 \\
\text { years }\end{array}$} & \multirow{3}{*}{$\begin{array}{l}61 / 2-8 \\
\text { years }\end{array}$} & \multirow{3}{*}{$\begin{array}{l}71 / 2-9 \\
\text { years }\end{array}$} & \multirow{3}{*}{$\begin{array}{l}81 / 2-10 \\
\text { years }\end{array}$} \\
\hline & 2007 & & & & & & & & & \\
\hline & 2008 & & & & & & & & & \\
\hline \multirow{3}{*}{$\mathrm{K}$ cohort } & 2003 & \multirow{3}{*}{$\begin{array}{l}31 / 2-5 \\
\text { years }\end{array}$} & \multirow{3}{*}{$\begin{array}{l}41 / 2-6 \\
\text { years }\end{array}$} & \multirow{3}{*}{$\begin{array}{l}51 / 2-7 \\
\text { years }\end{array}$} & \multirow{3}{*}{$\begin{array}{l}61 / 2-8 \\
\text { years }\end{array}$} & \multirow{3}{*}{$\begin{array}{l}71 / 2-9 \\
\text { years }\end{array}$} & \multirow{3}{*}{$\begin{array}{c}81 / 2-10^{-} \\
\text {years }\end{array}$} & \multirow{3}{*}{$\begin{array}{c}91 / 2-11 \\
\text { years }\end{array}$} & \multirow{3}{*}{$\begin{array}{c}10 \frac{1}{2}-12 \\
\text { years }\end{array}$} & \multirow{3}{*}{$\begin{array}{c}11 \frac{1}{2}-13 \\
\text { years }\end{array}$} \\
\hline & 2004 & & & & & & & & & \\
\hline & 2005 & & & & & & & & & \\
\hline
\end{tabular}

Figure 2: Longitudinal Study of Indigenous Children XXLSIC-Cohorts- (Kneebone et al., 2012).

The LSIC wasis designed with has-four overarching questions; are formulated under the guidance of the dataset Steering Committee, they are:- These are:

- What do Indigenous children need to have the best start in life and to grow up strong?

- What helps Aboriginal and Torres Strait Islander children to stay on track or get them back on track to become healthier, more positive and stronger?

- How are Aboriginal and Torres Strait Islander children raised?

- What is the importance of family, extended family and community in the early years of life and when growing up? (M Walter et al., 2017, p. 22).

To support these overarching research themes, the study collects data on an expansive range of topics including inter alia, physical and mental wellbeing, social and cognitive development,-including education, and family and community factors st(M Walter et al., 2017, p. 29). Accordingly, the LSIC is providing unequalled opportunities for current Indigenous and non-Indigenous researchers to contribute to improving outcomes for Aboriginallndigenous children, their-and families and teacherscommunities (Department of Social Services, 2016; M Walter et al., 2017). Yet it must be acknowledged that is not a perfect dataset; population statistics are often imbued with meaning derived from the dominant social norms, values and racial hierarchies of colonising nation-states. so,

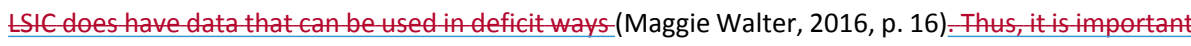
for researchers working with LSIC to not get trapped into looking at factors in a deficit manner. Accordingly, within this thesis there is a focus on strength.

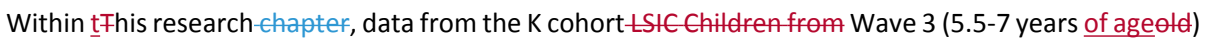
to Wave 9 (11.5-13 years of ageold) is analysed. Analysis is undertaken regarding how far teachers and parents believe the study child (hereinafter ' $\mathrm{SC}^{\prime}$ ) will go in their education. All data analysis procedures 
are undertaken using the statistical software program SPSS (Version 24). Specifically, in this paper the variable "How far do you think SC will go in their education" in W Waves 3 through 9 are analysed.

This variable consists of 5 responses: [1] Leave school before finishing secondary school; [2] Complete secondary school; [3] Complete a trade or vocational training course; [4] Go to university and complete a degree, and; [5] Obtain postgraduate qualifications at a university. This variable was theniswas recoded into a dichotomous yes/no-variable. This recoded variable is re-named: "Do you believe SC will finish their secondary education?" With [0] No and [1] Yes being the options. The variable was recoded dichotomously through option [1] staying the same, and options [2] through [5] being combined. Theis same question is asked of the parents ( $P 1_{-}$and $\mathrm{P}^{2}$ ) and teachers of the SC. Teacher responses are analysed in Wwaves 3 through 9, whereas P1 and P2 responses are only analysed in Waves 5, 8 and 9 as this question was not asked in other specifically reports on the percentage of parents and teachers in the study who selected 'Yes' or 'No in each Wave. Thereafter, significant difference between group means; specifically testing whether there is a statistically significant difference between Wave 3 teacher expectations and Wave 9 teacher expectations.

\section{Results}

\footnotetext{
2 The majority (87.7\%) of P1s analysed are the biological mothers with the remainder being close female relatives. P2's analysed are all male, 93.3\% are biological fathers; remainder are step-fathers or adoptive fathers.
} 


\section{Percentage of Primary Caregivers (P1) who Believe Child will Finish Their Secondary Education}

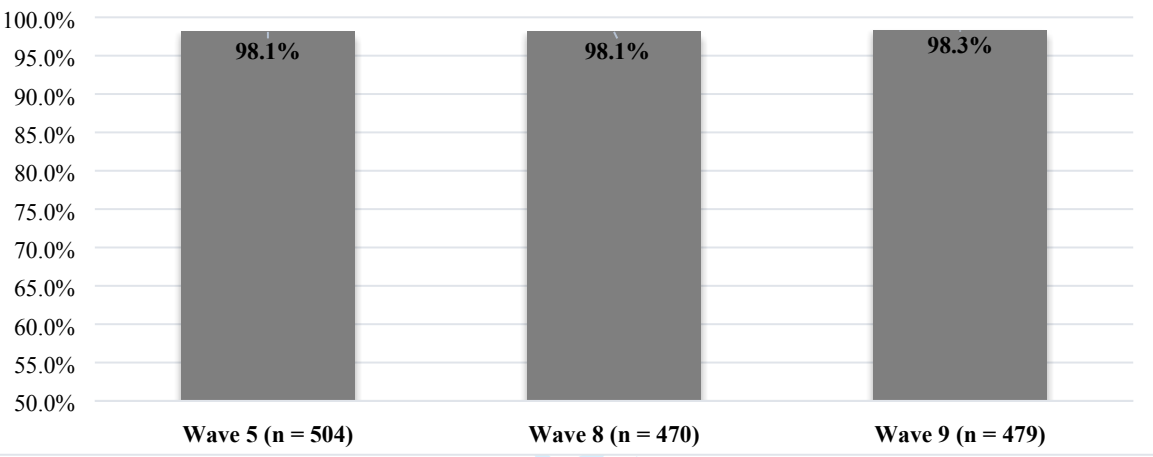

Figure 34:-1 Primary caregiver (P1) eExpectations regarding their children completion secondary education.

Percentage of Secondary caregivers (P2) who Believe Child will Complete Their Secondary Education

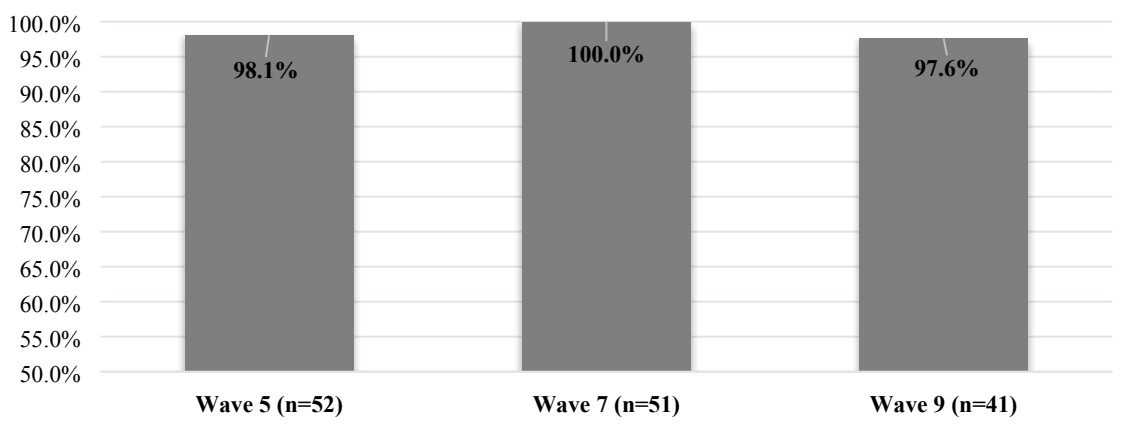

Figure 4: Secondary caregiver-2 (P2) eExpectations their children completion secondary education.

\section{Key findings}

close Close to all primary care giver's (P1s) and fathers Secondary caregivers $(\mathrm{P} 2 \mathrm{~s})$ believed their child would finish their secondary education in Waves 5, 8 and 9. Further, parent's responses did not significantly change over time. 


\section{Percentage of Teachers who Beleives Child will Finish Their Secondary Education}

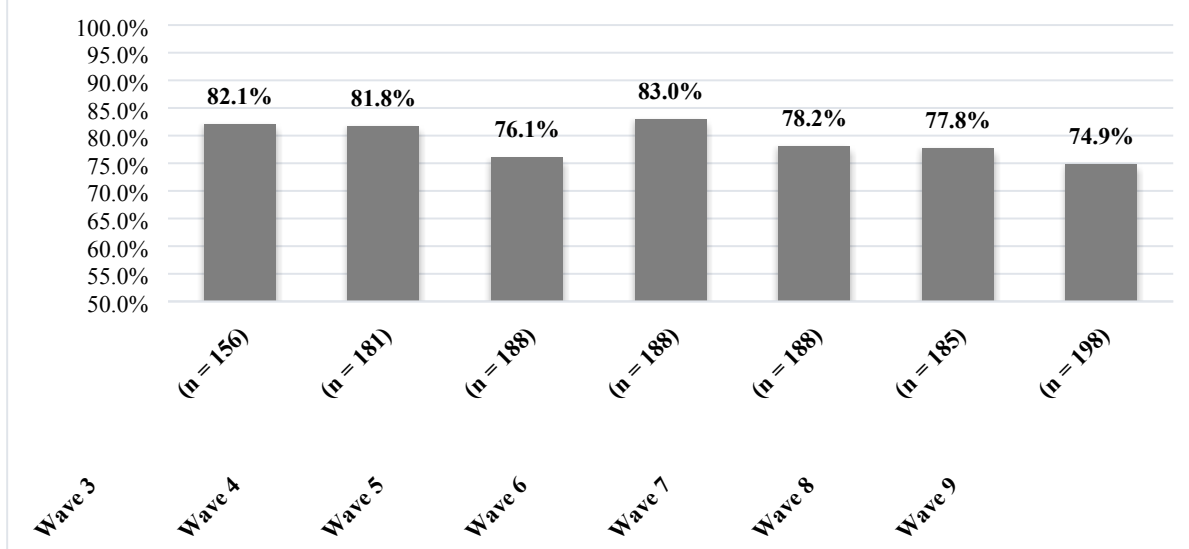

Figure 5: 4.3-Teacher eExpectations regarding whether Indigenous children will complete secondary education.

Summary of ANOVA (Wave 3 vs Wave 9)

\begin{tabular}{lllllll}
\hline & $\begin{array}{l}\text { Sum } \\
\text { Squares }\end{array}$ & of & \multicolumn{1}{l}{$\begin{array}{l}\text { Mean } \\
\text { Square }\end{array}$} & F & P \\
\hline Between Groups & 6521.4 & 1 & 6521.4 & 289.57 & $<.0001$ \\
\hline Fable 4.1 AVOVA & & & & &
\end{tabular}

Figure 6: ANOVA of Wave $3 v$ Wave 9.

One Way ANOVA Analysis indicates that there is a statistically significant difference $[F(1)=289.57$ $p=<.0001]$ between the group means of teacher expectations from wave 3 compared to Wave 9. Put simply this indicates that in Wave 9 , teacher's expectations of SC are significantly different (Lower) than teacher expectations from Wave 3.

\section{-Key findings}

Results indicate that Teachers' in higher-grade levels tend to report lower schooling completion expectations of the SC. As of wave 9 (when the children are between 11.5-13 years old), more than one quarter $(25.1 \%)$ of the teachers who responded indicated that they thought the child would leave school before finishing their secondary education, compared to $17.982 .1 \%$ of the teachers from wave 3 , this difference is statistically significant. as shown in table 4.1 . 


\section{Discussion}

Theis aim of this paper was to understand the expectations of teachers and Indigenous primary care givers regarding the secondary schooling completion rates of their Indigenous students/children, which has previously not been undertaken in Australia. Fo achieve this, data from the LSIC Waves 3 to 9 regarding parental and teacher year 12 completion expectations is analysed-Our results confirm and align with previous literature in finding that teachers have comparatively lowered expectations as children progress through their formal schooling years, whilst parents, conversely, maintain high-level high expectations of their children competing completing their secondary education. The expectation completion_ratess of formal year 12 schooling-rates between teachers and parents regarding Aboriginal and/or Torres Strait Islander children is a not surprisingly mismatched. Parents maintain consistently heightened expectations, approximately $98 \%$ for both mothers and fathers (see Figure 3 and 4), while teachers declined from 82.1 percent to 74.9 percent (see Figure 5)..

The data indicates that teacher's expectations of Indigenous children completing secondary education declines as the Indigenous children progress through their formal schooling levels. This finding correlates with other North American studies which described that sampled teachers had similar shifts in expectations throughout child maturation with students of minority ethnic groups (Jacoby-Senghor et al., 2016; Priest et al., 2018). It is of concern not only by virtue of the existence of such lowered expectations of Indigenous students per se, but also because this is shown to progressively worsen over time. In recognising that as Indigenous children mature to an age where their self-concept and self-esteem areis crystallised, and entrance into university becomes a consideration, it is imperative that they receive additional affirmation, instruction and support from their teachers. Given that lowered expectations from teachers likely correlates with less support, and subsequently students achieving less favourable results, intentions or possibilities for Indigenous youth to pursue higher education or employment requiring further training may be unduly hindered, impeded or jettisoned. This is of concern insofar as educational achievement has been identified as one of the primary means of Indigenous people moving out of poverty and intergenerational inequality into which they are often deeply embedded (Martin \& Walter, 2017; M Walter et al., 2017).

As expected, parents maintain exceptionallyremarkably highheightened expectations of their children regarding their high-schoolfformal secondary school completion._- In Wave 5, when the children are aged 7.5 to 9 years of age, $98.1 \%$ of primary caregivers thought their child would complete secondary education. In Wave $8(n=470)$ when the children are aged 10.5 to 12 years, $98.1 \%$ of parents felt their 

to 12 vears, $98.3 \%$ of parents thought their children would finish secondary education. Across the three Waves analysed, parent's expectations of their children's ability to complete secondary education, remain consistently high at over 98\%. Further, much like the pPrimary caregivers, secondary caregivers (mostly Indigenous fathers) also maintained extraordinarily remarkably heightened very high expectationsprospects of their children schooling completion. This is an important finding because parental belief of children from years 1- 6 haveis been found to contribute be a significant factoregarding favourabler high in educational attainmentaccomplishment through the development of their self-concept, and serves as a mitigating factor against structural inequalities facing Indigenous childrenyouth (Rubie-Davies et al., 2010; Wentzel, 1998).

Our paper reaffirms the need for rectifying the lowered expectations that teachers have for Indigenous children, recognising that teachers are the single most important 'in school' influence on student achievement over peers and other personnel (Hattie, 2009). In recognising that teacher willingness is required to facilitate best outcomes in changes to beliefs and behaviours, we suggest that all teachers (and teacher aids) should be required to receive instruction in cultural competency and sensitivity training, which has support in Australia ${ }_{L}$ as it is likely to produceing improvements in the outcomes for Indigenous children (Harrison \& Greenfield, 2011; Owens, 2015). It is key that teachers be steered way from any prejudicial stereotypes that they may have towards Indigenous people, and led to respect and have compassion for Indigenous communities, culture and children (Bodkin-Andrews \& Carlson, 2016; M Walter, 2014).

Reflexivity towards attitudes and behaviours shown by teachers working with Indigenous children is aan importantkey component of this process (Ryan, 2017). There is a deficit discourse that Indigenous students are lower achievers, which could has the potential to unconsciously impact teacher expectations of Indigenous students (Jacoby-Senghor et al., 2016). Teachers need to examine their own beliefs and behaviours to ascertain whether they have racial biases, and whether, and to what extent, this is affecting their practice. The Australian Professional Standards for Teachers could incorporate the importance of holding high expectations for Indigenous students under standard 1.4 (Strategies for teaching Aboriginal and Torres Strait Islander students) and/or 3.1 (Establish challenging learning goals). Furthermore, teacher cultural awareness programs could include an increase in unconscious bias training, alongside instruction en as to whyoutlining why maintaining high expectations of students (particularly those from minority groups) should be maintained of Indigenous studentsis needed to assist in ensuring the best results for students. More work is needed 
to further understand, the multifaceted issue of lowered teacher expectations, and in turn uncover how such a negative trend can be reversed. As Priest et al. (2018) states: perceptions of even small differences between groups can result in differential treatment with deleterious consequences.

accompanied by an exposition of relevant research literature and (if possible) local case-studies (Department of Education and Training, 2017; Landsman \& Lewis, 2012). It is suggested that this should be incorporated into tertiary educational training for teachers both in course content and as a component of their practical placement periods.

In light of the meta-analysis findings from - De Boer et al. (2018), one prominent strategy not mentioned is to improve teacher expectations_isthrough put forward by Sarra from the Stronger Smarter Institutes' (SSI) 2014 Position Paper. By implementing Sarra'susing the '-High Expectation Relationships'”- (H-ER), to create high-quality relationships between students, teachers, families and the community. S Sstudents will are likely feel moremore likely to feel supported and engaged in their education, as teachers are better able to understand and cater for their needs whilst maintaining highhighheightened lighted expectations (Stronger Smarter Institute, 2014).

Chris Sarra (2014) suggests that one meansthis may be able to to guard the classroom from racist and prejudicial practice is to require that teachers operate with High Expectation Relationships (hereinafter H-ER) ' $[H-E R$ ', which. This approach, which entails creating high-quality relationships between students, teachers and community Stronger Smarter Institute (2014)†. Sarra contends that when H-ER approaches are implemented within schools, students reportedly feel supported from their teachers and are more engaged in their education as a result. This may be is explained as $\underline{\text { because}_{\bar{T}}}$ as of thethrough using such strategies, strategy the product of teachers are positioned being able-to better understand and cater for theirstudent individual needs, irrespective of race or disability, and focus on the development of high-quality relationships with students. Collectively, this may lead to a greater sense of inclusion within the schooling environment, which-further promotes student (and teacher)promoting student engagement (Stronger Smarter Institute, 2014, p. 14).

(Stronger Smarter Institute, 2014, p. 5). There There are two overarching concepts of high expectation relationships used by the Stronger Smarter institute (SSI), these are: “-Ffair' $\underline{r}^{\prime}$ and 'firm' (see also Tatar and Horenczyk (2000). 'Firm'. The formerThe notion of fair requiresconsists of the desire and ability to activelactivey enquiry, e and listening to others tostudents to understand how they see the worldtheir worldview'- (Stronger Smarter Institute, 2014, p. 5). This aspect of the H-ER framework ean be described through (Mills, 2008): 'Socially just relating', is characterised through the cultivation and enaction of empathy and compassion, deep listening, genuine interest and a non--judgemental approach (Spillman, 2013). The concept of 'Ffirm consists of'-refers to '_critically reflective rRelating' 
(Spillman, 2013). This, which means having the-courage and firmness to calloutaddress times when the individual student or broader community (both internal and external to the school) is not performing their responsibilities appropriately (viz. with restraint, appropriate to the understanding ability of the child, free of malice or ill-intent). For-Within the school environment, this involves challenging the deficit biases that teachers may have (Stronger Smarter Institute, 2014, p.6), as well aswhile also enabling parents to more readily engage in their children's education. This close interaction of teachers with students may assist the former in discarding their-any held racial biases as a result of relating to the student as an individual, rather than as a member of a class; in turn, recognising their previously overlooked potential and capabilities... Critique of Sara here.

It must be acknowledged that the implementations of such interventions, should abide by the recommendations of De Boer et al. (2018). Namely, creating a broad array of support for teachers, by providing them with tangible Information on expectations within their own context, as well as involving them in the design and implementations of such interventions (De Boer et al., 2018, p. 196). Further, we acknowledge that high expectations must be balanced against the competency of the student, i.e. being firm and fair.

We also recognise that tertiary education must lead the way in ameliorating biases of freshly-minted teachers $s_{L}$ through the introduction of content and assessments which are embedded with Indigenous perspectives ${ }_{L}$ and focus on confronting racist stereotypes (Bodkin-Andrews \& Carlson, 2016; Peters, 2016; Zubrzycki et al., 2014). Education courses could incorporate Indigenous graduate attributes and further Indigenise to assist in this process (Page, Trudgett and Bodkin-Andrews 2019). Put simply we are articulating that current teacher education programs could and should be improved to help alleviate prejudicial behaviours. To assist in this process, the utilisation of Aboriginal Education Workers may_also be beneficial (Peacock \& Prehn, 2019).

accompanied by an exposition of relevant research literature and (if possible) local case studies (Department of Education and Training, 2017; Landsman \& Lewis, 2012). It is suggested that this should be incorporated into tertiary educational training for teachers both in course content and as a component of their practical placement periods. Limitations

It is important to acknowledge that-this study has several-limitations. One of the more prominent limitations is the lowered number of ehildren's-teachers participating in LSIC. This may bias the results by producing better teacher expectations presented in the dataset than what is reality; which may be

\begin{tabular}{l} 
Commented [HP7]: Already done in lit review \\
\hline Commented [MG8R8]: Delete? \\
\hline $\begin{array}{l}\text { Commented [HP9R8]: Jacob was gonna do something } \\
\text { here. }\end{array}$
\end{tabular}


explained insofar as the teachers who decided to take the time to partake in the study are potentially more invested educators than those who did not. Further, this study is limited by the age of the children, i.e. the SC's high school years have not been analysed as the data was unavailable at this time. This should be followed up as subsequent Waves are released to observe any further expectational variation.

A furtherAnother limitation is that quantitative measure of teachers' and caregivers' expectations of secondary school completion, is incapable of fully reflecting the expectations caregivers and teachers have of Indigenous children in their everyday lives at school. lit also cannot explain caregivers' and teachers' values, support, and backgrounds or other influences that might affect school experience, thatwhich may be contributing to Indigenous students' educational achievement. More research (Namely qualitative) is needed with regards to these important factors. Ffurther research may also be required that investigates how teachers' attitudes, beliefs and perspectives from the different year groups, impact on Indigenous students' outcomes. Nonetheless, the expectation measure of school completion remains an important consideration in evaluating teachers' expectations of Indigenous children.

of teachers and the exact impacted this has on specific variables such as reading and mathematics self-concept (Prehn et al., 2020) could be analysed in future research.

\section{Conclusion}

This researchpaper has aimed to understand the expectations that parentsparents and teachers have regarding chapter has shown that the parents of Aboriginal and Torres Strait ilslander children and their secondary schooling completion rates. have high expectations regarding their children's highschool completion, and that The results suggest that these high expectations of parents remain constant over the course of the child's primary school years. This is anvery positiveencouraging finding, as the literature indicates that parental's expectations play a pivotal role in their child's educational success. Unfortunately, Conversely, this chapter (re)confirms thatthe expectations held by teachers declinedecrease as have relatively low expectations of Aboriginallndigenous children progress through their formal schooling years. This is problematic because teachers play a central role in the lives of Indigenous children growing up strong, andstrong in their education, as well as assisting them to and overcomovercomeing the negative impacts of structural disadvantage.

To alleviate the lowered expectations that teachers have of Indigenous students, we suggest improvements to schooling systems and teacher training. The decolonisation and Indigenisation of the 
Australian schooling systemsystem requires further progression. Through providing a decolonised educational environment within schools favourable to Indigenous students and their worldviews, the Indigeneity of Aboriginal and Torres Strait Islander students is normalised, working to curtail othering and racism against their personhood. For teachers, decolonisation may lead to the abrogation of existing negative stereotypical assumptions as to Indigenous student educational prospects, thereby potentially improving aligning teachers' educational-expectations withto become closer to those of

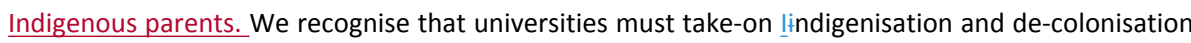
efforts within their curricula in order to ensure such change within the primary and secondary educational sectors; teaching degrees and diplomas must may need to incorporate more explicit instruction and assessment which addresses topics such as racial bias, cultural sensitivity, and Indigenous pedagogy, to adequately shape the next generation of teachers (see Page, Trudgett, and Bodkin-Andrews (2019). For teachers already engaged in the workforce, $e_{2}$ undertakinge professional development regarding unconscious bias, may expectations of Indigenous students. Australia is a wealthy First World state $\overline{,}_{\bar{\nu}}$ thus, through facilitating positive environments, and reconfiguring components to assist First-Nations children achieve educational success is an endeavour that can be achieved.

and has revealed that these expectations are significantly lower for teachers teaching the children in the older grades. As the literature indicates, this can result in several negative consequences that may worsen over time if trends continue. It is vital for the teachers, and the Australian education system, to be aware of the biases that may be present, to eliminate any soft bigotry that may be diminishing Aboriginal and Torres Strait Istander children's educational success. though again, it needs to be reiterated that the analysis of these quantitative measures cannot provide a full picture of such a complex and nuanced issue, rather this chapter provides some quantitative evidence, that points to the need for positive change in this space. 
Ali, R. (2010). The formation and enactment of teacher expectations of student achievement in private schooling. TEACH Journal of Christian Education, 4(1), 10.

Andersen, C. (2017). Parent and Teacher Disconnect. Paper presented at the Native American Indigenous Studies Association (NAISA) Conference, vancouver.

Baxter, L. P., \& Meyers, N. M. (2016). Increasing urban Indigenous students' attendance: Mitigating the influence of poverty through community partnership. Australian Journal of Education, 60(3), 211-228.

Bodkin-Andrews, G., \& Carlson, B. (2016). The legacy of racism and Indigenous Australian identity within education. Race Ethnicity and Education, 19(4), 784-807.

Bodkin-Andrews, G., O'Rourke, V., \& Craven, R. (2010). The utility of general self-esteem and domain-specific self-concepts: Their influence on Indigenous and non-Indigenous students' educational outcomes. Australian Journal of Education, 54(3), 277-306.

Bodkin-Andrews, G., Whittaker, A., Cooper, E., Parada, R. H., Denson, N., \& Bansel, P. (2017). Moving beyond essentialism: Aboriginal parental perceptions of school bullying and school engagement. In M. Walter, K. L. Martin, \& G. Bodkin-Andrews (Eds.), Indigenous Children Growing Up Strong (pp. 153-178). London: Springer.

Bornholt, L. J., \& Goodnow, J. J. (1999). Cross-generation perceptions of academic competence: Parental expectations and adolescent self-disclosure. Journal of Adolescent Research, 14(4), 427-447.

Castro, M., Expósito-Casas, E., López-Martín, E., Lizasoain, L., Navarro-Asencio, E., \& Gaviria, J. L. (2015). Parental involvement on student academic achievement: A meta-analysis. Educational research review, 14, 33-46.

Chaffey, G. W., Bailey, S. B., \& Vine, K. W. (2015). Identifying high academic potential in Australian Aboriginal children using dynamic testing. Australasian Journal of Gifted Education, 24(2), 24. 
Dandy, J., Durkin, K., Barber, B. L., \& Houghton, S. (2015). Academic expectations of Australian students from Aboriginal, Asian and Anglo backgrounds: Perspectives of teachers, traineeteachers and students. International Journal of Disability, Development and Education, 62(1), 60-82.

Davis-Kean, P. E. (2005). The influence of parent education and family income on child achievement: the indirect role of parental expectations and the home environment. Journal of family psychology, 19(2), 294.

De Boer, H., Bosker, R. J., \& van der Werf, M. P. (2010). Sustainability of teacher expectation bias effects on long-term student performance. Journal of Educational Psychology, 102(1), 168.

De Boer, H., Timmermans, A. C., \& Van Der Werf, M. P. (2018). The effects of teacher expectation interventions on teachers' expectations and student achievement: narrative review and meta-analysis. Educational Research and Evaluation, 24(3-5), 180-200.

Department of Education and Training. (2017). High Impact Teaching Strategies: Excellence in Teaching and Learning. Retrieved from Melbourne: https://www.education.vic.gov.au/documents/school/teachers/support/highimpactteachstr at.pdf

Department of Social Services. (2016). Footprints in Time - The Longitudinal Study of Indigenous Children: Wave 7.

Gentrup, S., Lorenz, G., Kristen, C., \& Kogan, I. (2020). Self-fulfilling prophecies in the classroom: Teacher expectations, teacher feedback and student achievement. Learning and Instruction, 66, 101296.

Gershenson, S., Holt, S. B., \& Papageorge, N. W. (2016). Who believes in me? The effect of studentteacher demographic match on teacher expectations. Economics of Education Review, 52, 209-224.

Glock, S., \& Krolak-Schwerdt, S. (2013). Does nationality matter? The impact of stereotypical expectations on student teachers' judgments. Social Psychology of Education, 16(1), 111127.

Good, T. L., Sterzinger, N., \& Lavigne, A. (2018). Expectation effects: Pygmalion and the initial 20 years of research. Educational Research and Evaluation, 24(3-5), 99-123.

Greenwald, A. G., \& Banaji, M. R. (1995). Implicit social cognition: attitudes, self-esteem, and stereotypes. Psychological review, 102(1), 4.

Harrison, N., \& Greenfield, M. (2011). Relationship to place: Positioning Aboriginal knowledge and perspectives in classroom pedagogies. Critical studies in education, 52(1), 65-76.

Hattie, J. A. (2009). Visible learning: A synthesis of 800+ meta-analyses on achievement. Abingdon: Routledge.

Jacoby-Senghor, D. S., Sinclair, S., \& Shelton, J. N. (2016). A lesson in bias: The relationship between implicit racial bias and performance in pedagogical contexts. Journal of Experimental Social Psychology, 63, 50-55.

Juang, L. P., \& Silbereisen, R. K. (2002). The relationship between adolescent academic capability beliefs, parenting and school grades. Journal of adolescence, 25(1), 3-18.

Jussim, L., \& Harber, K. D. (2005). Teacher expectations and self-fulfilling prophecies: Knowns and unknowns, resolved and unresolved controversies. Personality and social psychology review, 9(2), 131-155.

Kickett-Tucker, C., \& Coffin, J. (2011). Aboriginal self-concept and racial identity: Practical solutions for teachers. Two way teaching and learning, 155-172.

Kneebone, L. B., Christelow, J., Neuendorf, A., \& Skelton, F. (2012). Footprints in time: the longitudinal study of indigenous children: an overview. Family Matters(91), 62.

Koshy, P., Dockery, A. M., \& Seymour, R. (2019). Parental expectations for young people's participation in higher education in Australia. Studies in Higher Education, 44(2), 302-317.

Landsman, J., \& Lewis, C. W. (2012). White teachers/diverse classrooms: Creating inclusive schools, building on students' diversity, and providing true educational equity: Stylus Publishing, LLC. 
Luke, A., Cazden, C., \& Coopes, R. (2013). A summative evaluation of the stronger smarter learning communities project: Vol 1 and Vol 2.

Ma, X. (2001). Participation in advanced mathematics: Do expectation and influence of students, peers, teachers, and parents matter? Contemporary Educational Psychology, 26(1), 132-146.

Martin, K. L. (2017). Culture and identity: LSIC parents' beliefs and values and raising young Indigenous children in the twenty-first century. In M. Walter, K. L. Martin, \& G. BodkinAndrews (Eds.), Indigenous Children Growing Up Strong (pp. 79-99). London: Springer.

Martin, K. L., \& Walter, M. (2017). The Story of LSIC: It's All About Trust and Vision. In M. Walter, K. L. Martin, \& G. Bodkin-Andrews (Eds.), Indigenous Children Growing Up Strong (pp. 41-60). London: Springer.

Mau, W. C., \& Bikos, L. H. (2000). Educational and vocational aspirations of minority and female students: A longitudinal study. Journal of Counseling \& Development, 78(2), 186-194.

Mills, C. (2008). Making a difference: Moving beyond the superficial treatment of diversity. AsiaPacific Journal of Teacher Education, 36(4), 261-275.

Moodie, N., Maxwell, J., \& Rudolph, S. (2019). The impact of racism on the schooling experiences of Aboriginal and Torres Strait Islander students: A systematic review. The Australian Educational Researcher, 46(2), 273-295.

Oostdam, R., \& Hooge, E. (2013). Making the difference with active parenting; forming educational partnerships between parents and schools. European Journal of Psychology of Education, 28(2), 337-351.

Owens, K. (2015). Changing the teaching of mathematics for improved Indigenous education in a rural Australian city. Journal of Mathematics Teacher Education, 18(1), 53-78.

Page, S., Trudgett, M., \& Bodkin-Andrews, G. (2019). Creating a degree-focused pedagogical framework to guide Indigenous graduate attribute curriculum development. Higher Education, 78(1), 1-15.

Pantaleo, S. (2016). Teacher expectations and student literacy engagement and achievement. Literacy, 50(2), 83-92.

Patton, M. Q. (2014). Qualitative research \& evaluation methods: Integrating theory and practice: Sage publications.

Peacock, H., \& Prehn, J. (2019). The importance of Aboriginal Education Workers for decolonising and promoting culture in primary schools: an analysis of the longitudinal study of Indigenous children (LSIC). The Australian Journal of Indigenous Education, 1-7. doi:10.1017/jie.2019.13

Peters, N. (2016). Learning shame: Colonial narratives as a tool for decolonization. M. Battiste, Visioning a Mi'Kmaw humanities: Indigenizing the academy, 149-164.

Prehn, J., Peacock, H., \& Guerzoni, M. A. (2020). Academic self-concepts of Aboriginal and/or Torres Strait Islander children from the Longitudinal Study of Indigenous Children. The Australian Journal of Indigenous Education, 1-10. doi:10.1017/jie.2019.26

Priest, N., Slopen, N., Woolford, S., Philip, J. T., Singer, D., Kauffman, A. D., . . Williams, D. (2018). Stereotyping across intersections of race and age: Racial stereotyping among White adults working with children. PloS one, 13(9), e0201696.

Prout Quicke, S., \& Biddle, N. (2017). School (non-) attendance and 'mobile cultures': theoretical and empirical insights from Indigenous Australia. Race Ethnicity and Education, 20(1), 57-71.

Riley, T., \& Pidgeon, M. (2019). Australian teachers voice their perceptions of the influences of stereotypes, mindsets and school structure on teachers' expectations of Indigenous students. Teaching Education, 30(2), 123-144.

Riley, T., \& Ungerleider, C. (2012). Self-fulfilling prophecy: How teachers' attributions, expectations, and stereotypes influence the learning opportunities afforded Aboriginal students. Canadian Journal of Education/Revue canadienne de l'éducation, 35(2), 303-333.

Rimkute, L., Hirvonen, R., Tolvanen, A., Aunola, K., \& Nurmi, J.-E. (2012). Parents' role in adolescents' educational expectations. Scandinavian Journal of Educational Research, 56(6), 571-590. 
Rubie-Davies, C. M., Peterson, E., Irving, E., Widdowson, D., \& Dixon, R. (2010). Expectations of achievement: Student teacher and parent perceptions. Research in Education, 83(1), 36-53.

Ryan, C. (2017). Secondary School Teacher Effects on Student Achievement in Australian Schools. Retrieved from

Spillman, D. (2013). Towards a framework of dispositions, capabilities and cultural practices

for developing and enacting high-expectations relationships. University of Western

Sydney unpublished paper. .

Steele, C. M., \& Aronson, J. (1995). Stereotype threat and the intellectual test performance of African Americans. Journal of Personality and Social Psychology, 69(5), 797.

Stone, A., Walter, M., \& Peacock, H. (2017). Educational Outcomes For Aboriginal School Students In Tasmania: Is The Achievement Gap Closing? Australian and International Journal of Rural Education, 27(3), 90-110.

Stronger Smarter Institute. (2014). High-Expectations Relationships: a foundation for quality learning environments in all Australian schools. Stronger Smarter Institute: Limited Position Paper.

Tatar, M., \& Horenczyk, G. (2000). Parental expectations of their adolescents' teachers. Journal of adolescence, 23(4), 487-495.

Timmermans, A. C., Rubie-Davies, C. M., \& Rjosk, C. (2018). Pygmalion's 50th anniversary: the state of the art in teacher expectation research. In: Taylor \& Francis.

Trudgett, M., Page, S., Bodkin-Andrews, G., Franklin, C., \& Whittaker, A. (2017). Another brick in the wall? Parent perceptions of school educational experiences of Indigenous Australian children. In M. Walter, K. L. Martin, \& G. Bodkin-Andrews (Eds.), Indigenous Children Growing Up Strong (pp. 233-258). London: Springer.

Van den Bergh, L., Denessen, E., Hornstra, L., Voeten, M., \& Holland, R. W. (2010). The implicit prejudiced attitudes of teachers: Relations to teacher expectations and the ethnic achievement gap. American Educational Research Journal, 47(2), 497-527.

Vaught, S. E., \& Castagno, A. E. (2008). "I don't think I'm a racist": Critical Race Theory, teacher attitudes, and structural racism. Race Ethnicity and Education, 11(2), 95-113.

Visser, D. (1987). The relationship of parental attitudes and expectations to children's mathematics achievement behaviour. The Journal of Early Adolescence, 7(1), 1-12.

Walter, M. (2013). The Nature of Social Science Research. In M. Walter (Ed.), Social Research Methods (3rd ed.). South Melbourne: Oxford University Press.

Walter, M. (2014). The Race Blind: Denying Australian Indigenous Rights. In J. Green (Ed.), (pp. 4356). Nova Scotia: Fernwood Publishing.

Walter, M. (2016). Data politics and Indigenous representation in Australian statistics. Indigenous Data Sovereignty: Toward an agenda, 38, 79.

Walter, M., Dodson, M., \& Barnes, S. (2017). Introducing the Longitudinal Study of Indigenous Children. In M. Walter, K. L. Martin, \& G. Bodkin-Andrews (Eds.), Indigenous Children Growing Up Strong (pp. 15-40). London: Springer.

Wang, S., Rubie-Davies, C. M., \& Meissel, K. (2018). A systematic review of the teacher expectation literature over the past 30 years. Educational Research and Evaluation, 24(3-5), 124-179.

Watson, P. W. S. J., Rubie-Davies, C. M., Meissel, K., Peterson, E. R., Flint, A., Garrett, L., \& McDonald, L. (2019). Teacher gender, and expectation of reading achievement in New Zealand elementary school students: essentially a barrier? Gender and Education, 31(8), 1000-1019.

Wentzel, K. R. (1998). Parents' aspirations for children's educational attainments: Relations to parental beliefs and social address variables. Merrill-Palmer Quarterly (1982-), 20-37.

Wolfe, P. (1999). Settler colonialism: A\&C Black.

Wolfe, P. (2006). Settler colonialism and the elimination of the native. Journal of Genocide Research, 8(4), 387-409. doi:10.1080/14623520601056240

Yamamoto, Y., \& Holloway, S. D. (2010). Parental expectations and children's academic performance in sociocultural context. Educational Psychology Review, 22(3), 189-214. 
Zubrzycki, J., Green, S., Jones, V., Stratton, K., Young, S., \& Bessarab, D. (2014). Getting it right: Creating partnerships for change. Integrating Aboriginal and Torres Strait Islander knowledges in social work education and practice.

i The Longitudinal Study of Indigenous Children (LSIC) includes children that identify as Aboriginal, Torres Strait Islander and both Aboriginal and Torres Strait Islander. The usage of the term Indigenous in this paper is inclusive, and refers to both Aboriginal and/or Torres Strait Islander people. 